\title{
Androgens, oestrogens and endometrium: a fine balance between perfection and pathology
}

\author{
Douglas A Gibson 1 , Ioannis Simitsidellis, Frances Collins and Philippa T K Saunders \\ Centre for Inflammation Research, The University of Edinburgh, Edinburgh Bioquarter, Edinburgh, UK \\ Correspondence should be addressed to P T K Saunders: p.saunders@ed.ac.uk
}

\begin{abstract}
The endometrium is a complex multicellular tissue that is exquisitely sensitive to the actions of sex steroids synthesised in the ovary (endocrine system). Recent studies have highlighted a previously under-appreciated role for local (intracrine) metabolism in fine-tuning tissue function in both health and disease. In this review we have focused on the impact of oestrogens and androgens on endometrial function summarising data from studies on normal endometrial physiology and disorders including infertility, endometriosis and cancer. We consider the evidence that expression of enzymes including aromatase, sulphatase and AKR1C3 by endometrial cells plays an important role in tissue function and malfunction and discuss results from studies using drugs targeting intracrine pathways to treat endometrial disorders. We summarise studies exploring the spatial and temporal expression of oestrogen receptors (ERalpha/ESR1, ERbeta/ESR2 and GPER) and their role in mediating the impact of endogenous and synthetic ligands on cross-talk between vascular, immune, epithelial and stromal cells. There is a single androgen receptor gene and androgens play a key role in stromalepithelial cross-talk, scar-free healing of endometrium during menstruation and regulation of cell proliferation. The development of new receptor-selective drugs (SERMs, SARMs, SARDs) has reinvigorated interest in targeting receptor subtypes in treatment of disorders including endometriosis and endometrial cancer and some show promise as novel therapies. In summary, understanding the mechanisms regulated by sex steroids provides the platform for improved personalised treatment of endometrial disorders as well as novel insights into the impact of steroids on processes such as tissue repair and regeneration.
\end{abstract}

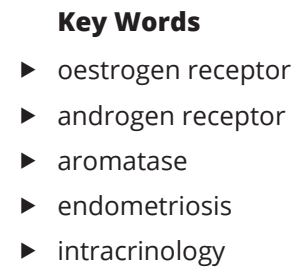

Journal of Endocrinology (2020) 246, R75-R93

\section{Introduction}

In women, the endometrium is divided into an inner/ luminal functional layer ('functionalis') and a basal layer ('basalis'). On its inner (luminal) aspect, columnar epithelial cells form a boundary between the fluid-filled uterine lumen and endometrial tissue containing glands, a well-developed vasculature, stromal mesenchyme (fibroblasts, perivascular cells) and a diverse population of immune cells. Between menarche and menopause, the endometrium responds to fluctuating levels of blood borne ovarian sex-steroid hormones (primarily $17 \beta$-oestradiol (E2) and progesterone (P)), with cyclical proliferation and differentiation ready to support a prospective pregnancy. In a non-pregnant cycle, the functional layer is shed during menstruation, but within a few days the luminal surface is healed and tissue integrity restored ready to resume the next cycle (Garry et al. 2009). 
While sex-steroid hormones are essential for the maintenance of normal uterine function and fertility, they may also contribute to the development of hormonedependent endometrial disorders that affect millions of women (Table 1). In this review we have focused on the impact of oestrogens and androgens on the function and malfunction of the endometrium, considering evidence for expression of receptors that can mediate their function as well as enzymes that modulate local bioavailability of steroids. The emergence of new classes of drugs that target receptors or enzymes and offer some potential as novel treatments for endometrial disorders is summarised.

\section{Oestrogen and androgen receptors and their expression in endometrial tissues}

\section{Overview of changes in tissue function during the menstrual cycle}

Based on evaluation of 8000 endometrial biopsies, Noyes et al. (1975) published a classification of the different stages of the menstrual cycle which is still considered the gold standard for histological staging. Although cycle length can vary between individuals, staging is typically based on an average menstrual cycle of 28 days: menstruation (day 1), proliferative phase (day 4 to 14 ) and secretory phase (days 16 to 28). Histologically, the functional layer thickens from about $2 \mathrm{~mm}$ recorded immediately after the menstrual phase to $14 \mathrm{~mm}$ prior to ovulation on day 14 . Following ovulation and formation of the corpus luteum (CL), there is a rapid rise in circulating concentrations of $\mathrm{P}$, which stimulates functional transformation of the stromal fibroblasts (decidualisation) resulting in shape change and reprogramming of gene expression leading to secretion of factors that regulate immune cell recruitment and receptivity (see comprehensive review by Gellersen et al. 2007). In the absence of a healthy blastocyst, the regression of the $\mathrm{CL}$ results in a rapid decrease in the circulating concentrations of ovarian-derived steroid hormones (progesterone withdrawal) and triggers a cascade of changes in endometrial tissue that results in tissue breakdown, piecemeal shedding and synchronous healing during menstruation (Garry et al. 2009).

\section{Structural and functional features of oestrogen and androgen receptors: genomic and non-genomic signalling}

Changes in expression of oestrogen- and androgendependent genes are orchestrated by interaction of their receptors with DNA-binding domains within gene promoters/enhancers as well as non-genomic signalling

Table 1 Hormone-dependent endometrial pathologies in women.

\begin{tabular}{|c|c|c|}
\hline Endometrial pathology & Incidence & Features \\
\hline $\begin{array}{l}\text { Implantation failure, } \\
\text { recurrent pregnancy } \\
\text { loss }\end{array}$ & $\begin{array}{l}\text { One in six couples have infertile } \\
\text { rates of implantation failure } \\
\text { difficult to determine other than } \\
\text { in IVF, RPL } 1-2 \%\end{array}$ & $\begin{array}{l}\text { Poor/out-of-phase decidual response. } \\
\text { Changes in immune cell cohorts (uNK). } \\
\text { Stromal cell senescence with age? }\end{array}$ \\
\hline $\begin{array}{l}\text { Heavy menstrual } \\
\text { bleeding (HMB) }\end{array}$ & $\begin{array}{l}\text { 20-30\% of women; may be worse } \\
\text { during perimenopause; } \\
\text { associated with fibroids }\end{array}$ & $\begin{array}{l}\text { Acute or chronic; FIGO classification of } \\
\text { causes (Palm-Coen) }\end{array}$ \\
\hline Endometriosis & $\begin{array}{l}\text { 10\% women of reproductive age; } \\
\text { may be asymptomatic. } \\
40 \% \text { of infertile patients may have } \\
\text { endometriosis }\end{array}$ & $\begin{array}{l}\text { Three subtypes - aetiology may be different. } \\
\text { Neuroinflammation and chronic pain. } \\
\text { Changes in peritoneal environment. }\end{array}$ \\
\hline Adenomyosis & $\begin{array}{l}\text { 20\% in women in gynaecology } \\
\text { clinics (higher in older women) }\end{array}$ & $\begin{array}{l}\text { Growth of endometrial fragments within } \\
\text { myometrial wall. } \\
\text { Myometrial thickening on ultrasound. } \\
\text { Association with endometriosis. }\end{array}$ \\
\hline Asherman's syndrome & $\begin{array}{l}\text { Estimates of incidence vary widely: } \\
3-45 \% \text { in infertile population? }\end{array}$ & $\begin{array}{l}\text { Adhesions within uterine cavity; risk } \\
\text { increased by endometrial ablation/surgery }\end{array}$ \\
\hline $\begin{array}{l}\text { Endometrial } \\
\text { hyperplasia }\end{array}$ & & $\begin{array}{l}\text { Increase in gland to stroma ratio when } \\
\text { compared with proliferative endometrium. } \\
\text { Some types may progress to endoCa }\end{array}$ \\
\hline Endometrial cancer & $\begin{array}{l}\text { Fourth most common cancer in UK } \\
\text { women; rates rising }\end{array}$ & $\begin{array}{l}\text { Risk increased by high BMI and Lynch } \\
\text { syndrome. Classifications based on } \\
\text { histology or genetics with 'unopposed' } \\
\text { oestrogen key risk factor for some } \\
\text { subtypes. }\end{array}$ \\
\hline
\end{tabular}

\author{
References \\ (Quenby et al. 2009, \\ Lucas et al. 2020) \\ (Whitaker \& Critchley \\ 2016) \\ (Horne et al. 2017, \\ Horne \& Saunders \\ 2019)
}

(Naftalin et al. 2012)

(Dreisler \& Kjer 2019)

(Sanderson

et al. 2017)

(Sanderson et al. 2017, Ryan et al. 2019)

For each pathology, an estimate of incidence, hallmark features and one or two key references are summarised. 
pathways initiated at the membrane. Steroid receptors contain three key structure-function domains: a variable amino-terminal domain, a highly conserved DNA-binding domain (DBD), and a less conserved carboxyl-terminal ligand binding domain (LBD). Differences in the sequence of amino acids located within a C-terminal ligand binding pocket play a critical role in ligand selectivity (Shiau et al. 1998, Nadal et al. 2017). A linker region situated between the DBD and the LBD functions as a flexible hinge with a nuclear localization signal: the proteins also contain multiple sites for phosphorylation (Lannigan 2003). There are two oestrogen receptors (alpha and beta) encoded by separate genes, ESR1 and ESR2, respectively: the full-length WT proteins they encode (hER $\alpha$ and hER $\beta 1$ respectively) bind a range of oestrogenic ligands with high affinity and specificity. Notably, analysis of natural ligand reported that, while $17 \beta$-oestradiol (E2) bound both receptors with high and equal affinity, oestrone (E1) had higher affinity for WT ERß(1) (Zhu et al. 2006). Multiple splice isoforms of both genes have been identified (reviewed in Gibson \& Saunders 2012). ER46 was the first splice variant of human ESR1 described (initially designated hER $\alpha-46$; Flouriot et al. 2000). ESR2 splice variants including $\mathrm{ER} \beta 2 / \mathrm{bcx}$ and ER $\beta 5$ are co-expressed in multiple reproductive tissues and reproductive cancers (Critchley et al. 2002, Saunders et al. 2002, Shaaban et al. 2008, Collins et al. 2009). In addition to ESR1 and ESR2, a family of closely related genes have been identified as encoding 'estrogen receptor related' proteins (ESRR1, ESRR2, ESRR3) which do not bind directly to E1 or E2 as they lack a proper binding pocket at their C-terminus but which may be activated by co-factors or other lipids (reviewed in Horard \& Vanacker 2003, Gibson \& Saunders 2012).

There is a single androgen receptor gene $(A R)$ located on the $\mathrm{X}$ chromosome. Elegant studies, including those using surface plasmon resonance, have revealed that the long AR N-terminal domain (NTD) is structurally important for receptor-dependent gene expression (Lavery \& McEwan 2008) and is a promising drug target (Ponnusamy et al. 2019). Several splice variant isoforms of AR have been identified with particular attention paid to their role in ligand-independent gene activation in advanced prostate cancers (Dehm \& Tindall 2011). Expression of AR variants including AR-V7 (exons 1/2/3/ CE3) has also been reported in primary breast cancers and breast cancer cell lines (Hickey et al. 2015), but a literature search did not identify any data related to their expression in endometrium or endometrial disorders.

There have been extensive studies on the functional consequences of steroid ligand binding to ERs and AR that have been well-reviewed elsewhere (McKenna et al. 1999, Gronemeyer et al. 2004). Briefly, ligand binding induces a conformational change in the ligand binding domain, dimerization and recruitment of co-regulators that play a critical role in regulating the hormonal response. Ligandactivated receptors bind directly to DNA sequences within regulatory regions of genes: sequences that are recognised by oestrogen (ERE - oestrogen response elements) or androgen (ARE - androgen response elements) receptors have been described (Brodie \& McEwan 2005, Carroll et al. 2006). Binding studies have also identified a number of so called 'pioneer' factors such as FOXA1 and GATA2 that can enhance direct binding of ER or AR to DNA (Carroll et al. 2005, He et al. 2014). ERs also regulate gene expression through protein-protein interactions with other transcription factors already bound on DNA ('tethering') - examples of tethering mechanisms include binding to the transcription factor Sp1 which has been implicated in regulation of the progesterone receptor gene (Petz et al. 2004) and ER $\beta$-dependent induction of gene expression in human endometrial endothelial cells (Greaves et al. 2013).

Oestrogens and androgens can also induce changes in cell function following binding to ERs or ARs localised in the cell membrane. These 'non-genomic' signalling cascades can be initiated through the membrane localization of the classical receptors following palmitoylation and interaction with scaffolding proteins or by hormoneresponsive $G$ protein-coupled transmembrane receptors (GPCRs) (Hammes \& Levin 2007). One of the most extensively investigated GPCRs is GPER (originally named GPR 30, also known as GPER1), which was cloned from breast cancer cells in 1997 and binds oestrogens with nanomolar affinity (Carmeci et al. 1997). Information on GPCRs that bind to androgens is less comprehensive, but several candidates including GPRC6A have been identified in cancer cells (Ye et al. 2019).

A recent review provided a useful summary of the wide range of different non-genomic signalling pathways and how the different genomic and non-genomic pathways may interact (Wilkenfeld et al. 2018).

\section{Expression and functional impact of oestrogen receptors during the menstrual cycle}

We, and others, have used highly specific antibodies to explore temporal and cell-specific patterns of expression of $E R \alpha, E R \beta, E R R s$ and $A R$ in endometrium during the normal cycle (Critchley \& Saunders 2009, Young 2013). We have documented cell-specific and temporal 
immunoexpression of full-length ER $\alpha$ (ER66) in both normal endometrium and in endometrial pathologies including cancer (Critchley et al. 2002, Collins et al. 2009). In full-thickness sections of endometrium (Fig. 1), immunoexpression of ER $\alpha$ is intense in the epithelial glands and in the stroma of both the functional and basal layers: endothelial cells lining the blood vessels appear immuno-negative (Critchley et al. 2001). Expression is downregulated in the functional layer during the secretory phase in response to the rising levels of progesterone

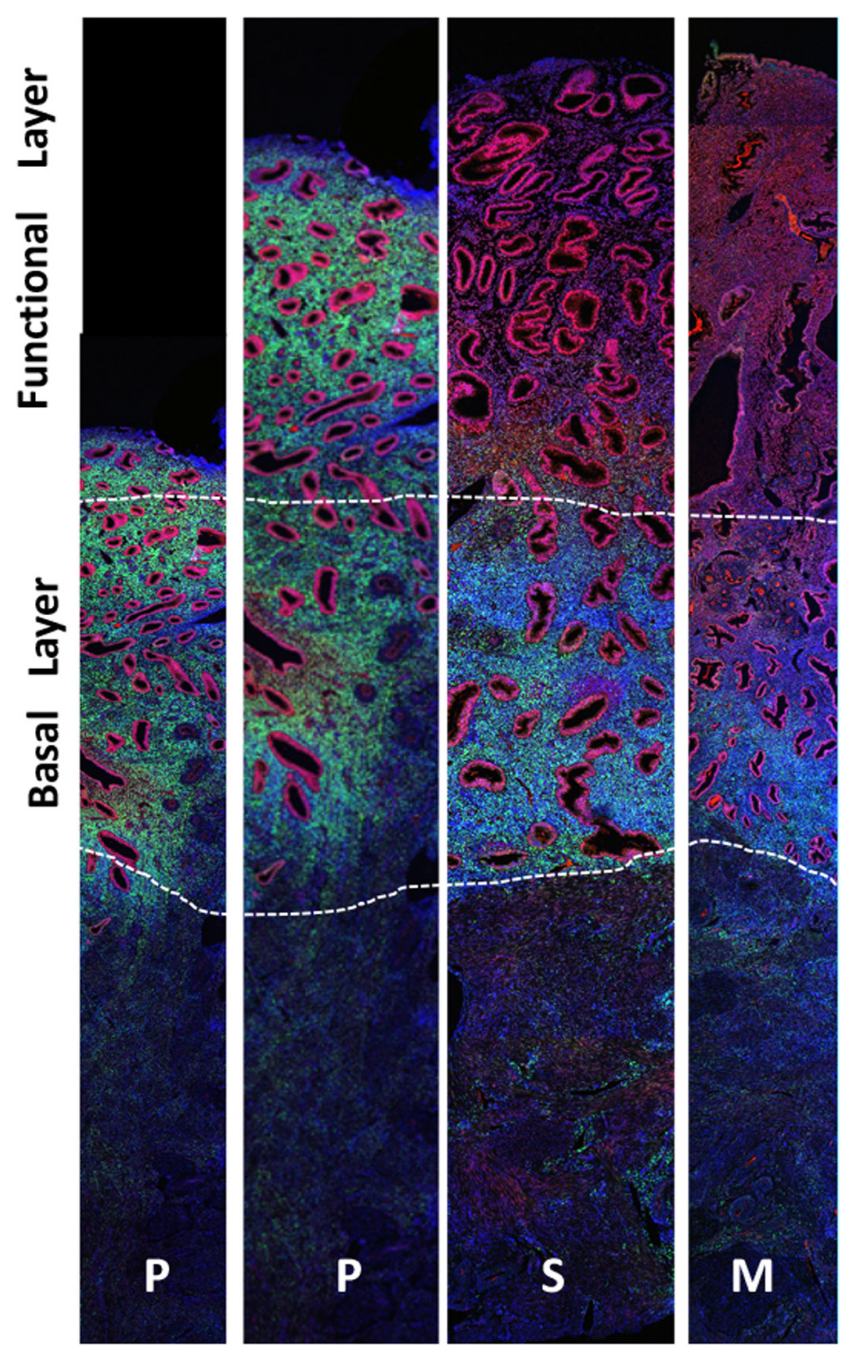

Figure 1

Expression of oestrogen receptor alpha (ER $\alpha)$ and androgen receptor (AR) in full-thickness samples from the human uterus. The tissue is divided into functional and basal layers supported on the myometrium below and bounded on upper surface by the luminal epithelium. ER $\alpha$ (red stain) is abundant in epithelial cells in the proliferative phase but downregulated in the secretory phase. AR (green) is localised to stromal cells in the basal and functional layers during the proliferative phase but only expressed in the basal stromal cells in the secretory phase when its expression is upregulated in epithelial cells. P, proliferative phase; S, secretory phase; $\mathrm{M}$, menstrual phase.

(C) 2020 Society for Endocrinology Published by Bioscientifica Ltd. Printed in Great Britain
(Fig. 1) (Lessey et al. 1988, Young 2013). We have recently explored expression of ER46 in the endometrium using a combination of immunohistochemistry and Western blotting (Gibson et al. 2020). Notably, the variant protein was co-localised with ER66 in cell nuclei during the proliferative phase with striking expression in a population of uterine natural killer cells (uNK) implicated in vascular remodelling (Quenby et al. 2009, Gibson et al. 2015).

Studies in mice suggest a complex role for ER $\alpha$ in epithelial and stromal compartments of the endometrium. For example, the role of epithelial ER $\alpha$ was studied using a conditional knockout mouse which was ovariectomised and then treated with a single intraperitoneal injection of $0.25 \mu \mathrm{g} 17 \beta$-estradiol (E2) in $100 \mu \mathrm{L}$ sesame oil. Analysis of samples recovered 2, 24 or $72 \mathrm{~h}$ after E2 injection revealed that epithelial ERo was dispensable for the proliferative response observed at $2 \mathrm{~h}$ but essential for responses at 24 and $72 \mathrm{~h}$ (Winuthayanon et al. 2014). Similar studies also revealed a critical role for ER $\alpha$ in paracrine regulation of stromal decidualization in this species (Pawar et al. 2015). The pattern of expression of ER $\beta$ is distinct from that of $E R \alpha$, with highest concentrations of mRNA encoding fulllength ER $\beta 1$ in the secretory phase and immunoexpression in epithelial, stromal, endothelial cells and immune cells (Critchley et al. 2001): ER $\beta 1$ is not downregulated in the functional layer during the secretory phase (Bombail et al. 2008). Studies in mice with Esr 2 knockout have suggested a less striking phenotype than in the Esr1 knockout, although a re-evaluation of the evidence by Hapangama et al. (2015) concluded that sustained E2 stimulation of endometrial epithelial cells via ER $\beta$ might induce apoptosis. There has been some disagreement about the cyclical expression (or otherwise) of ER $\beta$ in endometrial endothelial cells (Critchley et al. 2001, Lecce et al. 2001). Our own study using endothelial cells from different vascular beds demonstrated those originally isolated from endometrium or myometrium were $\mathrm{ER} \beta+/ \mathrm{ER} \alpha-$ and revealed cell-specific impacts of an ER $\beta$-selective agonist on gene expression (Greaves et al. 2013). In contrast, studies using isolated human uNK cells suggest their response to oestrogens may be complex involving rapid membraneinitiated signalling via ER46 (Gibson et al. 2020) and/or binding to ER $\beta$ (Gibson et al. 2015). Treatment of isolated uNK cells with either oestrone (E1) or E2 promotes cell migration and secretion of chemokine (C-C motif) ligand 2 (CCL2) (Gibson et al. 2015). These studies highlight the importance of endogenous oestrogens in the dynamic interplay between different endometrial cell types that play a critical role in preparation for pregnancy. 
Expression of proteins encoded by human ESR2 splice variant mRNAs (ERß2, ER $\beta 5$ ) has been detected in human endometrial cells (Critchley et al. 2002, Collins et al. $2009,2019)$. Notably, these variants may also be present in primates (Sierens et al. 2004) but are not expressed in rodents. In vitro studies have demonstrated that the variants can have a functional impact on endometrial cell function by forming heterodimers with full-length isoforms (Collins et al. 2019). Expression of ERRs has also been detected in human endometrium with cell-based studies, highlighting the potential for them to alter cell metabolism or ER $\alpha$-dependent cell functions (Bombail et al. 2010a,b).

Plante et al. (2012) examined expression of GPER in endometrium using RT-qPCR and immunohistochemistry reporting maximal expression in the proliferative phase. An earlier study by Kolkova et al. (2010) claimed protein expression was less variable than the mRNA and immunostaining was more intense in the epithelial cells than stroma throughout the cycle. GPER may be involved in neoplastic transformation of endometrium (Jacenik et al. 2016) or in promotion of HIF $1 \alpha$-induced expression of MMPs in endometrial stromal cells in women with endometriosis (Zhang et al. 2017). A number of GPER knockout mice have been generated using different targeting strategies: females are fertile with no obvious reproductive defects, although impacts on obesity and vasculature have been claimed (Prossnitz \& Hathaway 2015).

\section{Expression and functional impact of androgen receptors during the menstrual cycle}

Immunostaining for AR in full-thickness endometrial tissue sections (Fig. 1) (Marshall et al. 2011) detected intense staining in stromal fibroblasts which exhibited cyclical variation in the functional layer but remains unchanged within the basal compartment across the cycle. How this difference in expression within closely adjacent cells is regulated remains unknown. Epithelial cells in the functional layer upregulate expression of AR in response to falling levels of progesterone in a normal cycle or following administration of anti-progestins and this is associated with reduced proliferation (Narvekar et al. 2004, Marshall et al. 2011). We have identified androgenregulated genes in primary human endometrial stromal cells, several of which (e.g. CITED2, HIF1a, CD44) are implicated in networks that protect cells against stress and apoptosis (Marshall et al. 2011). These data coupled with the observation that AR expression remains unchanged in the stromal cells of basal compartment at time of menses (Garry et al. 2009) prompted us to investigate whether androgens might also play a role in regulating endometrial breakdown and repair using a mouse model that recapitulates key features of menstruation in women (Cousins et al. 2014, 2016a,b). In this model, administration of a single injection of DHT at the time of progesterone withdrawal to induce menstruation had a striking impact on both tissue breakdown and restoration of tissue homeostasis. Although our understanding of the role of androgens in endometrial tissue function is still incomplete, we identified changes in expression of matrix metalloproteinases (MMP3, 9) which are implicated in breakdown of human endometrium (Cousins et al. 2016a).

\section{Expression of enzymes implicated in biosynthesis and metabolism of oestrogens and androgens in endometrial tissue}

In recent years there has been a rapid increase in evidence to support a role for local tissue ('intracrine') regulation of endometrial steroids (Gibson et al. 2013, 2016a, $2018 b$ ). Key findings have included direct measurement of steroids in endometrial tissue homogenates recovered during the menstrual cycle: notably Huhtinen and colleagues reported they did not parallel those in blood (Huhtinen et al. 2012, 2014). In women (but not in mice), the adrenals are an important source of sulphated steroids that circulate at high concentrations in the blood but are unable to bind directly to the steroid receptors. A brief summary of enzymes detected in endometrial tissue and their substrates is provided in Fig. 2 with a few complementary references discussed subsequently. Readers interested in the topic of intracrine steroids are recommended to read the comprehensive review by Konings et al. which includes a systematic search for papers reporting expression of steroidogenic enzymes in pre- and postmenopausal endometrium (Konings et al. 2018).

Briefly, a strong case has been made that the 'inactive' adrenal steroid dehydroepiandrosterone (DHEA) is an important precursor of bioactive androgens in women (Labrie et al. 2005), a proposal which has been supported by detection of all the enzymes that regulate conversion of DHEA via intermediates to testosterone, DHT or oestrogens (Gibson et al. 2013, 2016a, 2018c). Catalano and colleagues reported increased expression of $A K R 1 C 3$ in the early secretory phase (Catalano et al. 2011), consistent with results obtained using an in vitro model of stromal decidualisation (Gibson et al. 2016a). 


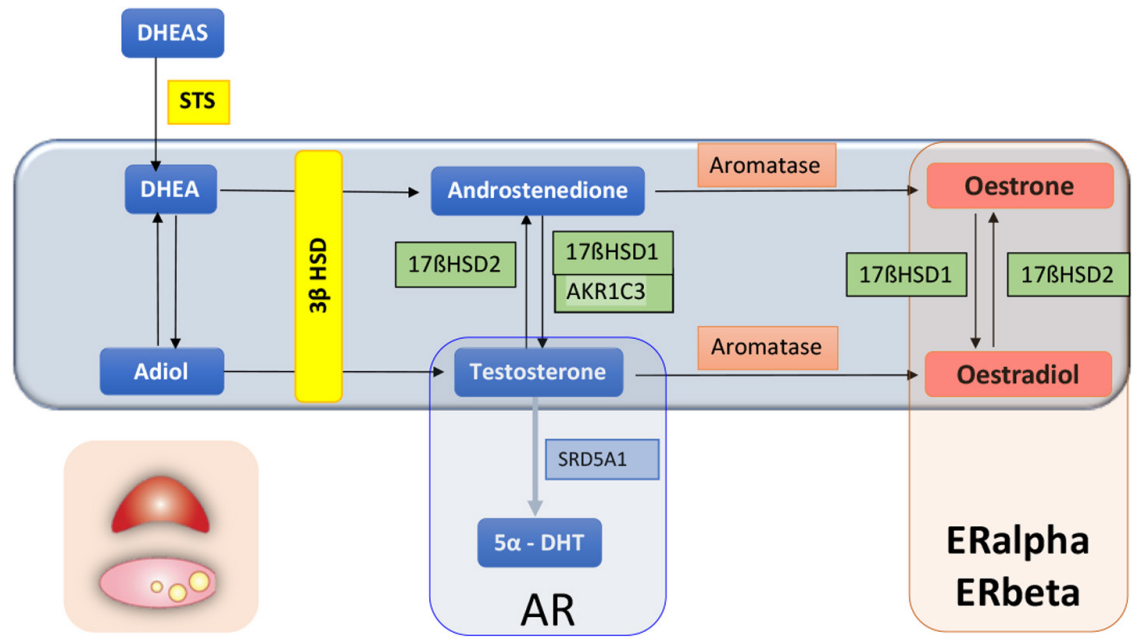

\section{Figure 2}

Simplified diagram of key biosynthetic steroids implicated in intracrine biosynthesis of oestrogens and androgens within endometrial tissue. In pre-menopausal women both the adrenal and ovary are the primary sites of biosynthesis of steroids. Expression of all enzymes illustrated has been validated in human tissue or primary endometrial stromal cells exposed to a decidualisation stimulus (Gibson et al. 2013, 2016a, 2018b). For a more comprehensive steroidogenic pathway, readers are referred to the review by Konings et al. (2018).
Inter-conversion of active/inactive oestrogens and androgens is mediated via 17 $\beta$-hydroxysteroid dehydrogenase isozymes, of which several isoforms are expressed in endometrium. For example, $17 \beta$ HSD type 1 is responsible for production of testosterone and E2, from A4 and E1, respectively, whereas $17 \beta \mathrm{HSD} 2$ catalyses the opposite reaction. HSD17B2, expressed in glandular epithelial cells, is markedly increased in the secretory phase (Maentausta et al. 1991), and reported overexpression of $17 \beta$ HSD 2 is a feature of endometrium in women with disorders such as endometriosis, adenomyosis, and/or leiomyomas (fibroids) rather than those who are diseasefree (Kitawaki et al. 2000).

Expression of steroid sulphatase (STS) in endometrial tissue can catalyse conversion of DHEAS to DHEA (Fig. 2) but can also increase the concentration of E1 by removal of sulphate moieties from E1S. Using an in vitro model of decidualisation, we have confirmed expression of both STS and aromatase (CYP19A1) in endometrial stromal cells with evidence that both enzymes contribute to production of oestrogens during decidualisation (Gibson et al. 2013, 2018a).

\section{Endometrial disorders: altered expression of enzymes and receptors implicated in disease aetiology}

\section{Implantation failure and recurrent miscarriage}

Timely and efficient decidualization of endometrial stromal cells in response to ovarian-derived progesterone is essential for the generation of an endometrial microenvironment that can support and nurture the implanting blastocyst. Disruption of decidualization is implicated in implantation failure and miscarriage.
Studies in mice using aromatase inhibitors (AI) demonstrated local intra-uterine production of E2 is critical for establishment of pregnancy (Das et al. 2009). In women, E2 is produced during decidualisation of endometrial stomal cells which regulates uNK cell migration (Gibson et al. 2015, 2020). Given the evidence that disturbances in the numbers/location of uNK cells can predispose women to experiencing a miscarriage (Lash et al. 2016), these data are consistent with a role for $\mathrm{E} 2$ in regulating the endometrial microenvironment during the establishment of pregnancy.

We have demonstrated that during in vitro decidualisation of primary human endometrial stromal cells there is a significant increase in the expression of AKR1C3, the enzyme responsible for the conversion of androstenedione to testosterone, which is also accompanied by increased secretion of testosterone into the culture medium (Gibson et al. 2016a). In addition, blocking AR action using flutamide during in vitro decidualisation revealed a role for AR-mediated gene expression of osteopontin, a protein implicated in receptivity (Gibson et al. 2016a). Further studies using primary human endometrial stromal cells from women of advanced reproductive age suggested that the agerelated decline in adrenal steroids may have an impact on the ability of the endometrium to support a pregnancy and that increased availability of adrenal precursors enhanced androgen production and secretion of decidualisation markers (Gibson et al. 2018c). Intravaginal supplementation with DHEA has shown promising results in alleviating postmenopausal vaginal dryness and atrophy in clinical trials without any adverse effects (Labrie 2019), but delivery into the endometrium of premenopausal women has not been tested. Other studies have reported a positive impact of DHT on stromal cell 
decidualisation and resistance to oxidative stress (using hydrogen peroxide) (Kajihara et al. 2012), expanding our understanding of the potentially beneficial role of androgens as direct modulators of endometrial function as well as precursors of oestrogen biosynthesis (see review by Gibson et al. 2016b).

Failure to downregulate ER $\alpha$ during the secretory phase (see Fig. 1 and discussion) has been reported in women with defects in uterine receptivity (Lessey et al. 2006). A complementary study using samples from women with unexplained infertility also showed that in these patients elevated expression of ERo in the midluteal phase was associated with reduced expression of glycodelin-A, low levels of which have been implicated in recurrent implantation failure (Dorostghoal et al. 2018). There is no information about dysregulation of ER $\beta$ in implantation failure. Fertility problems in women with polycystic ovaries and excess androgens might relate to overstimulation of AR signalling pathways, but currently the evidence is quite limited (Schulte et al. 2015).

\section{Endometrial cancer}

The majority of endometrial cancers (EC) present with abnormal endometrial bleeding in postmenopausal women: rates are rising particularly in younger women, with obesity considered a significant contributing factor (Table 1, reviewed by Sanderson et al. 2017). EC are historically classified as type 1 or type 2 ; type 1 is the most commonly diagnosed form (about 80\% of the cases), is considered oestrogen-dependent and characterised by hyperplastic proliferation of the endometrial glands. A large number of studies have investigated the source and impact of oestrogens in endometrial cancer with landmark papers including those by Sasano and collaborators who reported evidence of increased immunoexpression of aromatase, STS and $17 \beta$ HSD enzymes in both endometrial hyperplasia and EC (Sasano et al. 1996, Utsunomiya et al. 2001, 2004). A recent comprehensive systematic review considered the evidence that intracrine metabolism contributes to EC (Cornel et al. 2019). The authors highlighted the importance of sulphatase and aromatase enzymes in the generation of E1 and E2 within endometrial cancer tissue in promoting a pro-oestrogenic environment favouring proliferation of epithelial cells (Cornel et al. 2019). The authors sounded a note of caution by highlighting the variability between individuals and methodologies which may explain some variations in drug responses (discussed subsequently).
The best evidence for an impact of androgens on EC risk has come from studies in women with polycystic ovarian disease, where the risk of type 1 cancers is higher in women with symptoms of androgen excess such as hirsutism and irregular periods (Fearnley et al. 2010). Tanaka et al. reported DHT was elevated in endometrioid endometrial adenocarcinoma tissues compared with that in normal endometrial tissues (8.0 fold) in a group of 41 patients (Tanaka et al. 2015). These results have been complemented by reports that AKR1C3 (conversion from A4 to testosterone) and $5 \alpha$-reductase (reduction of testosterone to DHT) are both expressed in EC (Ito et al. 2016, Gibson et al. 2018a).

Expression of ER $\alpha$, ER $\beta 1$ and splice variant isoforms of ER $\beta$ (ER $\beta 2$, ER $\beta 5$ ) in EC have been documented (Collins et al. 2009, 2019). In a recent paper we highlighted the potential that ER $\beta 5$, a variant unable to bind directly to $\mathrm{E} 2$, may still influence the response of EC to oestrogens by forming heterodimers with ER $\alpha$ (Collins et al. 2019). High GPER expression is predictive of poor survival in endometrial cancers (Smith et al. 2007). Prossnitz and colleagues have reported interesting results using ER $\alpha$ negative/GPER-positive cells which suggest activation of downstream signalling in response to SERMs such as tamoxifen may explain why women treated with this drug are at higher risk of EC (Petrie et al. 2013). We, and others, have reported widespread expression of AR in EC (reviewed in Gibson et al. 2014). Evidence that loss of $\mathrm{AR}$ is associated with poorer prognosis, reports that AR was elevated in metastases (Kamal et al. 2016), and that androgens may be anti-proliferative in EC cells have raised the prospect that SARMs should be explored for this cancer as well as those of breast (see subsequent section). There are no reports of AR variants being expressed in EC.

\section{Endometriosis}

Endometriosis is an oestrogen-dependent neuroinflammatory pain disorder characterised by the presence of 'lesions' of endometrial-like tissue in sites outside the uterus (Horne \& Saunders 2019). Endometriosis and adenomyosis are often found in the same patient and may share a common aetiology (Yovich et al. 2019). Infertility is a common co-morbitity of endometriosis and differences between expression profiles of mRNAs, miRNA and proteins in endometrial biopsies from controls and women with endometriosis have been reported (Burney et al. 2007, 2009) and have recently been reviewed (Bulun et al. 2019). Notably, there remain differing views as to whether receptivity is or is not affected (Lessey \& Kim 2017, 
Miravet-Valenciano et al. 2017). Studies comparing the impact of a decidualisation stimulus on isolated endometrial stromal cells have reported alterations in the expression of steroidogenic enzymes in cells from women with endometriosis (Aghajanova et al. 2009). Blunted responses to progesterone, often termed 'progesterone resistance', are considered a hallmark of the disorder (Aghajanova et al. 2010, Bulun et al. 2010). Some have questioned whether this property is an innate feature of the eutopic endometrial cells or acquired when they grow in ectopic sites (McKinnon et al. 2018).

Some of the best evidence for the importance of intracrine action of steroids has come from studies comparing concentrations of steroids in lesions and eutopic endometrium in women with endometriosis (Huhtinen et al. 2012, 2014). To complement mass spectrometry data, expression of enzymes in lesions such as aromatase, AKR1C3 and STS has been measured with evidence that their overexpression is responsible for generation of a lesion tissue environment rich in oestrogens that can bind ERs or GPER (Rizner 2009, 2016). Notably, aromatase appears to be involved in local biosynthesis of both E2 and the pro-inflammatory regulator prostaglandin E2 (Attar \& Bulun 2006). Upregulation of ER $\beta$ is also considered a hallmark of the altered microenvironment of lesions, which may promote the impact of oestrogens on inflammation, angiogenesis or pain pathways (Bulun et al. 2012, Greaves et al. 2014a,b).

\section{Adenomyosis}

Adenomyosis is a condition characterised by the presence of heterotopic endometrial glands and stroma within the myometrium and has traditionally been difficult to diagnose as it can present with symptoms such as infertility, pain and heavy menstrual bleeding, which are also characteristics of other conditions, including endometriosis and fibroids (Pontis et al. 2016). Recent advances in imaging offer hope for improved understanding of its presentation and pathogenesis (Chapron et al. 2020). Altered gene expression in the endometrium of women with adenomyosis has been reported, although results have been based on small numbers of samples (Herndon et al. 2016, Xiang et al. 2019). It has been suggested that development of adenomyosis may involve mechanisms activated but not resolved during endometrial tissue injury with a common aetiology to some forms of endometriosis (Donnez et al. 2018 , 2019). Studies using tissue recovered from women with adenomyosis have identified increased expression of
GPER and some association between GPER polymorphisms with the disease; however, it must be noted that study populations have been small (Li et al. 2017, Hong et al. 2019). In vitro studies have identified pathways promoting E2-induced overproliferation of uterine smooth muscle cells from women with adenomyosis (Sun et al. 2015). Immunostaining of tissue sections from adenomyosis uteri have detected changes in ER $\alpha$, reduced PR and elevated expression of ER $\beta$ (Mehasseb et al. 2011) and aromatase (Barcena de Arellano et al. 2013), all consistent with an oestrogen-dependent disease. In older papers, expression of AR has been reported (Horie et al. 1992).

\section{Drugs targeting sex steroid metabolism}

\section{Aromatase inhibitors}

An excellent historical summary of the discovery of aromatase, identification of increased expression in quadrants of breast containing a tumour, and the development and refinement of aromatase inhibitors (AIs) has been published by leaders in the field (Santen et al. 2009). The development of highly effective $3^{\text {rd }}$ generation AIs (anastrozole, letrozole, exemestane) led to clinical trials for a number of indications including postmenopausal breast cancer, gynaecomastia in men and ovarian cancer (Miller et al. 2001, Santen et al. 2009, Langdon et al. 2017). One key reproducible finding has been a lower rate of EC and venous thrombosis in women treated with AIs compared with those treated with tamoxifen (Chlebowski et al. 2015). The ClinicalTrials. gov website lists 22 trials with search terms endometrial cancer+aromatase inhibitor with the main focus being on women with more advanced disease. Many trials are not yet completed but evidence of benefit in some ER+ cancers has been reported. For example, in 40 women treated with exemestane, there was remission in $10 \%$ and lack of progression after 6 months in 35\% of the patients (Lindemann et al. 2014). The PARAGON trial, a phase 2 open label study using anastazole in 82 patients with ER and/or PR positive hormonal therapy naive metastatic endometrial cancer, reported clinical benefit in $44 \%$ of patients (Mileshkin et al. 2019), although results from other trials have been disappointing and may have been influenced by obesity in the target population (van Weelden et al. 2019). Some promising results have been reported following treatment of women with the rarer cancer low grade endometrial sarcoma with AIs (reviewed in Pannier et al. 2019). 
Letrozole and anastrozole have also been evaluated in both pre- and postmenopausal women with endometriosis (Pavone \& Bulun 2012). These authors propose that AIs appear to be a suitable therapy for endometriosisassociated pain in women who are postmenopausal by targeting the intracrine oestrogen biosynthesis that contributes to sustained symptoms in this age group. Recent advances have included development of vaginal ring delivery systems for co-administration of anastrozole and the androgenic progestin levonorgestrel (LNG) as a potential therapy for endometriosis-associated pain: a phase I trial reported promising findings (Schultze-Mosgau et al. 2016). While these results seem promising, a recent ESHRE guideline that considered whether AIs should be given in combination with contraceptives or other therapies concluded that due to side effects they should only be prescribed to women after all other options for medical or surgical treatment are exhausted (Dunselman et al. 2014). AIs have also been suggested as therapies for adenomyosis but with the caveat that further studies are required (Vannuccini et al. 2018).

\section{Sulphatase inhibitors}

A number of potent STS inhibitors have been developed with the primary indication being treatment of hormonedependent cancers (Day et al. 2009, Purohit \& Foster 2012). The compound STX64 (Irosustat) was effective in blocking oestrogen synthesis in endometrial cancer cells in vitro and was tested as a therapy for advanced endometrial cancer before being discontinued as a mono-therapy by Ipsen (Pautier et al. 2017). Irosustat has recently been used as an addition to aromatase inhibitors in women with advanced ER+ breast cancer and reported as having a positive clinical impact (Palmieri et al. 2017). Another inhibitor, estradiol-3-O-sufamate (E2MATE), has been reported which deceased STS activity in human endometrial explants and decreased lesion weight and size but did not alter systemic oestrogens in a mouse model of endometriosis (Colette et al. 2011). E2MATE, under the trade name PGL2001, has been shown to reduce STS activity in endometrium when given once a week for 4 weeks (Pohl et al. 2014); the same drug was used in a trial for treatment of endometriosis-associated pain (NCT01631981) but results have not been reported.

\section{Hydroxysteroid dehydrogenase inhibitors}

$17 \beta \mathrm{HSD} 1$ inhibitors were originally developed to target the biosynthesis of bioactive E2 in hormone-dependent breast cancer (Day et al. 2008). Recently, with evidence for expression of $17 \beta \mathrm{HSD} 1$ in endometriosis lesions, their use has been expanded to treatment of endometriosis with promising results reported (Delvoux et al. 2014). The role of 17ßHSD5/AKR1C3 in metabolism of steroids and prostaglandins, both of which are implicated in endometriosis-associated pain, make it an attractive target as a novel therapy for this disorder. A number of inhibitors have been developed with the Bayer compound BAY1128688 showing sufficient promise for it to be used in a phase 2 randomised clinical trial to assess efficacy of different doses in 121 women with symptomatic endometriosis. The trial (NCT03373422) was terminated after 8 months due to an increased incidence of liver toxicity highlighting the challenge of developing drugs that may target enzymes present in multiple tissues (van Weelden et al. 2019). In their recent review, Rizner \& Penning (2020) concluded that the 'hepatotoxicity effect was probably compound related which does not preclude AKR1C3 as a target' and that development of other drugs targeting this enzyme alone or in combination with other targets is continuing (Wangtrakuldee et al. 2019).

\section{Dual/combined targeting}

While initial studies have focused on mono-therapies, a new generation of drugs with dual actions has also been developed - examples include those that target aromatase and STS (DASI, Purohit \& Foster 2012) or STS and 17ßHSD1. While some in vitro studies seem promising, clinical trials are yet to be completed (reviewed in Potter 2018).

\section{Drugs targeting oestrogen and androgen receptors and their potential to treat endometrial disorders}

The solving of the crystal structure of nuclear ERs as well as detailed modelling of the impact of ligand binding on conformation, recruitment of co-factors and gene expression laid the foundation for the development of synthetic ligands that exhibit selectivity, tissue-specific agonism, antagonism or induce receptor degradation; a comprehensive perspective and background is provided by Burris et al. (2013). Table 2 summarises the specificities and properties of some of the novel non-steroidal ligands developed to target ERs and AR, a number of which have been investigated in the context of endometrial disorders and are discussed subsequently. 
Table 2 Non-steroidal drugs targeting oestrogen and androgen receptors.

\begin{tabular}{|c|c|c|}
\hline Name & Receptor activity & Clinical trials \\
\hline PPT & ER $\alpha$ selective agonist & Stimulates epithelial cell proliferation \\
\hline DPN & $\begin{array}{l}\text { ERbeta selective } \\
\text { agonist }\end{array}$ & Stimulates endometrial endothelial cells \\
\hline LNS8801 & GPER agonist & $\begin{array}{l}\text { Phase } 1 \text { open label clinical trial in advanced solid and } \\
\text { hematologic cancers }\end{array}$ \\
\hline G36 & GPER antagonist & Improved selectivity compared to G15 \\
\hline Tamoxifen & SERM & $\begin{array}{l}\text { Treatment and prevention of ER } \alpha \text {-positive breast cancers } \\
\text { in pre- and post-menopausal women. Agonist action in } \\
\text { endometrium }\end{array}$ \\
\hline Raloxifene, Evista & SERM & $\begin{array}{l}\text { Prevention of invasive breast cancer in post-menopausal } \\
\text { women. Positive effects on bone, cognition, } \\
\text { cardiovascular system }\end{array}$ \\
\hline Fulvestrant, Faslodex & SERD & $\begin{array}{l}\text { Licensed as first line endocrine management for } \\
\text { advanced breast cancer in post-menopausal women }\end{array}$ \\
\hline Bazedoxifene, Duavee & SERM/SERD & $\begin{array}{l}\text { Positive impacts on bone, approved for HRT, SERD in } \\
\text { endometrium }\end{array}$ \\
\hline GTx24, Enobosarm & SARM & $\begin{array}{l}\text { Muscle wasting in cancer, breast cancer, urinary stress } \\
\text { incontinence }\end{array}$ \\
\hline GTx007, Andarine & SARM, partial agonist & Tested in preclinical models; issues with use in doping \\
\hline GSK2881078 & SARM, long half life & $\begin{array}{l}\text { Muscle loss in patients with chronic disease } \\
\text { (discontinued) } \\
\text { Improved muscle mass in healthy women }\end{array}$ \\
\hline AZD3514 & SARD & $\begin{array}{l}\text { Moderate anti-tumour activity in advanced castrate- } \\
\text { resistant PCa. Significant levels of nausea and vomiting }\end{array}$ \\
\hline
\end{tabular}

References

(Frasor et al. 2003)

(Greaves et al. 2013)

NCT04130516

(Dennis et al. 2011)

(Jordan 2003)

(Muchmore 2000)

(Blackburn et al. 2018)

(Fanning et al. 2018)

(Gao \& Dalton 2007)

(Kearbey et al. 2007)

(Neil et al. 2018)

(Omlin et al. 2015)

Each drug is identified by its common abbreviation or registered name, the activity as reported in the literature, whether it has been used in one or more clinical trial(s), and a key reference is provided.

DPN, 2,3-bis(4-hydroxyphenyl)-propionitrile; G36, ( \pm )-(3a $R^{\star}, 4 S^{*}, 9 \mathrm{bS}$ )-4-(6-bromo-1,3-benzodioxol-5-yl)-3a,4,5,9b-tetrahydro-8-(1-methylethyl)-3Hcyclopenta[c]quinoline; GPER, G protein-coupled oestrogen receptor 1; PPT, 4,4',4"-(4-propyl-[1 H]-pyrazole-1,3,5-triyl)trisphenol; SARM, selective androgen receptor modulator; SERD, selective oestrogen receptor degrader; SERM, selective oestrogen receptor modulator.

\section{Oestrogen receptors}

Agonists and antagonists with selectivity for $\operatorname{ER} \alpha, \mathrm{ER} \beta$ and GPER have been validated using a range of cell based and animal models (Table 2). When Frasor et al. (2003) compared the effect of $4 \times$ daily injections of 4,4', 4" -(4-propyl-[1H]-pyrazole-1,3,5-triyl)trisphenol (PPT) or 2,3-bis(4-hydroxyphenyl)-propionitrile (DPN) to immature (d21) female mice, they noted differences in tissue response which they attributed to activation of ER $\alpha$ or ER $\beta$ respectively. PPT caused epithelial cell proliferation, increased uterine weight and expression of lactoferrin but decreased Ar mRNA. In contrast, DPN did not increase uterine weight or luminal epithelial cell proliferation but appeared able to reduce stimulation by PPT. These findings are consistent with a large body of work that implicates $\mathrm{ER} \alpha$ as the major regulator of oestrogendependent proliferation in the uterus (Hewitt \& Korach 2003, Winuthayanon et al. 2017). In contrast, it appears that $\operatorname{ER} \beta$ may have other functions including specific roles in inflammation and angiogenesis (Critchley et al. 2001, Gibson \& Saunders 2012, Greaves et al. 2013, Gibson et al. 2015). There have been fewer studies focussed on GPER, but when Zhang et al. (2017) treated primary endometrial stromal cells with E2, G1 (( \pm$)-1-\left[\left(3 a R^{*}, 4 S^{*}, 9 b S^{*}\right)-4-(6-\right.$ bromo-1,3-benzodioxol-5-yl)-3a, 4,5,9b-tetrahydro$3 H$-cyclopenta[c]quinolin-8-yl]-ethanone) or G15 $\left(\left(3 \mathrm{aS} *, 4 R^{*}, 9 \mathrm{~b} R^{*}\right)\right.$-4-(6-bromo-1,3-benzodioxol-5-yl)$3 \mathrm{a}, 4,5,9 \mathrm{~b}-3 H$-cyclopenta[c]quinolone), they reported that stimulation of GPER with G1 mimicked the impact of E2 and resulted in stabilisation of HIF protein and increased expression of VEGF and MMP9. The Prossnitz group generated a GPER antagonist $\left(\mathrm{G} 36,( \pm)-\left(3 \mathrm{aR} *, 4 S^{*}, 9 \mathrm{~b} S^{*}\right)\right.$ 4-(6-bromo-1,3-benzodioxol-5-yl)-3a,4,5,9b-tetrahydro8-(1-methylethyl)-3H-cyclopenta[c]quinolone, Table 2) with improved selectivity and reported that it can block multiple E2-mediated second messenger signalling pathways and endometrial cell proliferation (Dennis et al. 2011).

\section{Selective oestrogen receptor modulators (SERMs)}

Selective oestrogen receptor modulators (SERMs) were developed to treat ER $\alpha$-positive breast cancers with the ideal SERM being one that acts as an antagonist in breast but an agonist in bone (Burris et al. 2013). The evolution in our understanding of tissue selective activities of ligand-activated receptors coupled with the 
discovery of different ER subtypes and splice variants has resulted in several generations of SERMs. Tamoxifen is a first generation SERM that displays agonism in the endometrium, increasing EC risk; second generation SERMs such as Raloxifene do not agonize endometrial growth and are associated with lower risk of EC and may have additional positive effects on cognition and the cardiovascular system (Muchmore 2000). Other SERMs have a mixture of agonist/antagonist activity in endometrium, agonist activity in bone and antagonism in breast (Pickar et al. 2018).

\section{Selective oestrogen receptor degraders (SERDs)}

Selective oestrogen receptor degraders (SERDs) antagonize $\mathrm{ER} \alpha$ and induce its degradation, resulting in a decrease in ER $\alpha$ protein levels: they do not show agonist properties in other tissues (Kieser et al. 2010). Fulvestrant was the first SERD to be approved as a therapeutic and is commonly used as a treatment for advanced breast cancer (Blackburn et al. 2018). Although originally marketed under the trade name Faslodex by AstraZeneca, manufacture of generic versions has been approved by the US Federal Drugs Administration. A number of new generation SERDs are in development (Pepermans \& Prossnitz 2019), one of which is bazedoxifene (BZA), a compound which exhibits SERD properties in breast cancer with beneficial properties in bone and no adverse impact on endometrium leading to its approval for hormone replacement therapies (Pickar et al. 2018). Recent mechanistic studies suggest BZA may be useful in treating cancers which contain ERo mutants (Fanning et al. 2018). In addition to activation by endogenous oestrogens, there is evidence that GPER may also be activated by SERMs/SERDs developed to target ER $\alpha$ which may explain some apparent discordant results in ERo negative cancers (see review by Meyer et al. 2011).

\section{Androgen receptors}

Selective androgen receptor modulators (SARMs) have been developed to support the beneficial impacts of AR-mediated cell function in bone and muscle without the adverse side effects seen with high doses of testosterone or DHT (gynaecomastia, aggression, prostate hyperplasia) (Burris et al. 2013, McEwan 2013) (Table 2). New generation SARMs have been proposed as therapeutics for women suffering from breast cancer, muscle wasting or urinary incontinence and a number of clinical trials have been undertaken to evaluate their use for these indications (Brodie \& McEwan 2005, Dalton et al. 2011).

\section{Targeting oestrogen receptors in endometrial disorders}

A high proportion of low grade EC express ER $\alpha$ as well as progesterone receptors. In a recent systematic review, van Weelden and colleagues highlighted the progestins as a first-line hormonal therapy and use of antioestrogens as an alternative therapy option, highlighting results from ten trials using SERMs or SERDs as monotherapies between 1981 and 2013 (van Weelden et al. 2019). All studies showed some beneficial response to therapy, although results were variable and the authors concluded that tamoxifen or a combination of tamoxifen and progestin might be the best choice when selecting second-line hormonal treatment. In subsequent studies, the SERM Ospemifene has been shown as an effective in treatment of vaginal symptoms in postmenopausal women (Archer et al. 2019) and only acts as an agonist in endometrium in high doses. The SERD fulvestrant/faslodex (Table 2) has been investigated as a treatment for endometrial cancer in phase I/II trials, although well-tolerated, it has low oral bioavailability and further trials are needed (Bogliolo et al. 2017). Another recent study suggested dual targeting of ER $\alpha$ with tamoxifen and ERR $\alpha$ with XCT790 may be beneficial for EC treatment, but this requires further validation (Mao et al. 2019).

While administration of SERMs/SERDs may be appropriate for postmenopausal women with cancer, their use in younger women with non-malignant endometrial disorders such as endometriosis is more challenging with data limited to promising results in preclinical models (Kulak et al. 2011, Khine et al. 2018). The observation that $\operatorname{ER} \beta$ is highly expressed in endometriosis lesions and the development of ER $\beta$-selective agonists such as ER $\beta$-041 with apparent anti-inflammatory properties provided a rationale for testing them as therapies for endometriosis with promising results obtained in preclinical models (Harris 2006). Several clinical trials were conducted with ERß-041, but no positive outcomes were reported. In a recent review, Guo and Groothuis highlighted a number of reasons why drugs targeting ER $\beta$ including the SERM Fulvestrant and ER $\beta$-041 failed to deliver the patient benefit in clinical trials. The reasons highlighted included, but were not limited to, animal models that did not recapitulate long-established disease, translation of dose from rodent to women and incomplete understanding of the role of ER $\beta$ antagonism in pain mechanisms (Guo \& Groothuis 2018). SERMs are not considered suitable therapies for adenomyosis (Pontis et al. 2016). The SERM Ormeloxifene, developed for use as a contraceptive, https://joe.bioscientifica.com https://doi.org/10.1530/JOE-20-0106 (c) 2020 Society for Endocrinology Published by Bioscientifica Ltd.
Printed in Great Britain 
has also shown promising results in treating heavy menstrual bleeding (HMB) in perimenopausal women in India (Pati et al. 2017).

GPER has also been investigated as a target for treatment of endometriosis with reports that the GPER agonist G-1 induced cell cycle arrest and apoptosis of stromal cells derived from ovarian endometriosis cysts (Mori et al. 2015). GPER has been implicated in E2-stimulated nociceptive pain in endometriosis, with results in a mouse model showing administration of the selective GPER antagonist G36 inhibited the pain response (Alvarez et al. 2014). Properly designed clinical trials are needed to explore GPER as a target for relief of painful symptoms in endometriosis in women.

\section{Targeting androgen receptors in endometrial disorders}

The development of SARMs has prompted renewed interest in targeting of AR in reproductive disorders while also raising concerns related to side effects including hirsutism that are a hallmark of excess androgens in PCOS. Transgender individuals may be one group who might benefit from SARMs, as administration of high concentrations of testosterone can result in abnormal uterine bleeding and metabolism to oestrogen may explain increased rates of endometrial cancer (Grimstad et al. 2019), but there are no registered clinical trials.

Danazol is a synthetic androgen first used as a treatment in the 1970s: it binds AR with high affinity and is also reported to reduce the activity of a number of enzymes including steroid sulphatase (Carlstrom et al. 1984). Danazol has anti-proliferative effects on uterine cells (Kauppila et al. 1985). A systematic review of RCTs using Danazol to treat endometriosis concluded that treatment was associated with reduced lesion size and relief of pain symptoms and that women who took Danazol were more satisfied with their treatment compared with women who had placebo treatment (Farquhar et al. 2007). The anti-proliferative and hormone-suppressive activities of Danazol has formed the basis of treatments for adenomyosis (Vannuccini et al. 2018) and heavy menstrual bleeding (Beaumont et al. 2007) with efficacy being demonstrated. The androgenic activity of Danazol is associated with side effects including hirsutism and deepening of the voice and it is contraindicated for women at risk of pregnancy because of the risk of virilisation of the fetus (Farquhar et al. 2007). These side effects have limited its use and prompted efforts to develop therapies that are less virilising.

(c) 2020 Society for Endocrinology Published by Bioscientifica Ltd. Printed in Great Britain
Using a mouse model, we have compared the impact of DHT with Danazol and new generation SARMs GTx-024 and GTx-007 (Table 2) and found that both Danazol and GTx-024 restored uterine weight of ovariectomised female mice to that of intact animals, while GTx-007 had no similar effect (Simitsidellis et al. 2019). These preclinical studies highlight the importance of considering impacts on the endometrium when women are included in clinical trials using SARMs (Dalton et al. 2011, Neil et al. 2018). While SARMs have been used in clinical trials for treatment of breast cancer, they have not as yet been tested as treatments for endometrial cancer or endometriosis (Narayanan et al. 2018). Standard medical treatment for HMB involves targeting of the progesterone receptor either with the androgenic progestagen levonorgestrol delivered in an intra-uterine device or with newly developed selective progesterone receptor modulators (SPRMs; Maybin \& Critchley 2016). Interestingly, administration of progesterone receptor antagonists or SPRMs such as UPA (ulipristal acetate) as a treatment for heavy menstrual bleeding results in a significant increase in expression of AR (Whitaker et al. 2017) which may, in part, explain their anti-proliferative action. Treatment with new generation SARMs is yet to be investigated.

\section{Summary and future directions}

The endometrium is a dynamic tissue which, by virtue of its expression of high affinity receptors, is exquisitely sensitive to the actions of oestrogens and androgens. Temporal and spatial changes in tissue function in response to steroids play a critical role in preparation for pregnancy and in breakdown and shedding if pregnancy does not occur. Balanced regulation of sex-steroid action is essential for endometrial function and is controlled via local metabolism and cell- and tissue-specific expression of steroid receptors/isoforms. Drugs targeting steroid metabolising enzyme activity and/or receptor function have reported efficacy in several endometrial disorders, but their use has often been limited due to lack of tissue specificity and undesirable side-effect profiles. Recent development of drugs that selectively target steroid receptors such as next generation SERMs, SERDs, SARMs and SARDs show promise as new therapeutics, but further preclinical studies and clinical trials are needed to determine if these drugs have efficacy specifically for the indication of endometrial disorders. 


\section{Declaration of interest}

The authors declare that there is no conflict of interest that could be perceived as prejudicing the impartiality of this review.

\section{Funding}

Funding for salaries and research in the Saunders laboratory has been supported by MRC programme grants MR/N024524/1 and G1100356/1.

\section{References}

Aghajanova L, Hamilton A, Kwintkiewicz J, Vo KC \& Giudice LC 2009 Steroidogenic enzyme and key decidualization marker dysregulation in endometrial stromal cells from women with versus without endometriosis. Biology of Reproduction 80 105-114. (https://doi. org/10.1095/biolreprod.108.070300)

Aghajanova L, Velarde MC \& Giudice LC 2010 Altered gene expression profiling in endometrium: evidence for progesterone resistance. Seminars in Reproductive Medicine 28 51-58. (https://doi. org/10.1055/s-0029-1242994)

Alvarez P, Bogen O \& Levine JD 2014 Role of nociceptor estrogen receptor GPR30 in a rat model of endometriosis pain. Pain 155 2680-2686. (https://doi.org/10.1016/j.pain.2014.09.035)

Archer DF, Simon JA, Portman DJ, Goldstein SR \& Goldstein I 2019 Ospemifene for the treatment of menopausal vaginal dryness, a symptom of the genitourinary syndrome of menopause. Expert Review of Endocrinology and Metabolism 14 301-314. (https://doi.org/10.1080/ 17446651.2019.1657008)

Attar E \& Bulun SE 2006 Aromatase and other steroidogenic genes in endometriosis: translational aspects. Human Reproduction Update 12 49-56. (https://doi.org/10.1093/humupd/dmi034)

Barcena de Arellano ML, Oldeweme J, Arnold J, Schneider A \& Mechsner S 2013 Remodeling of estrogen-dependent sympathetic nerve fibers seems to be disturbed in adenomyosis. Fertility and Sterility 100 801-809. (https://doi.org/10.1016/j. fertnstert.2013.05.013)

Beaumont HH, Augood C, Duckitt K \& Lethaby A 2007 Danazol for heavy menstrual bleeding. Cochrane Database of Systematic Reviews $\mathbf{3}$ CD001017. (https://doi.org/10.1002/14651858.CD001017.pub2)

Blackburn SA, Parks RM \& Cheung KL 2018 Fulvestrant for the treatment of advanced breast cancer. Expert Review of Anticancer Therapy 18 619-628. (https://doi.org/10.1080/14737140.2018.1473038)

Bogliolo S, Cassani C, Dominoni M, Orlandini A, Ferrero S, Iacobone AD, Viazzo F, Venturini PL, Spinillo A \& Gardella B 2017 The role of fulvestrant in endometrial cancer. Expert Opinion on Drug Metabolism and Toxicology 13 537-544. (https://doi.org/10.1080/17425255.2016. 1244264)

Bombail V, Macpherson S, Critchley HO \& Saunders PT 2008 Estrogen receptor related beta is expressed in human endometrium throughout the normal menstrual cycle. Human Reproduction 23 2782-2790. (https://doi.org/10.1093/humrep/den298)

Bombail V, Collins F, Brown P \& Saunders PT 2010a Modulation of ER alpha transcriptional activity by the orphan nuclear receptor ERR beta and evidence for differential effects of long- and short-form splice variants. Molecular and Cellular Endocrinology 314 53-61. (https://doi. org/10.1016/j.mce.2009.09.007)

Bombail V, Gibson DA, Collins F, MacPherson S, Critchley HO \& Saunders PT $2010 b$ A role for the orphan nuclear receptor estrogenrelated receptor alpha in endometrial stromal cell decidualization and expression of genes implicated in energy metabolism. Journal of Clinical Endocrinology and Metabolism 95 E224-E228. (https://doi. org/10.1210/jc.2010-0154)
Brodie J \& McEwan IJ 2005 Intra-domain communication between the N-terminal and DNA-binding domains of the androgen receptor: modulation of androgen response element DNA binding. Journal of Molecular Endocrinology 34 603-615. (https://doi.org/10.1677/ jme.1.01723)

Bulun SE, Cheng YH, Pavone ME, Xue Q, Attar E, Trukhacheva E, Tokunaga H, Utsunomiya H, Yin P, Luo X, et al. 2010 Estrogen receptor-beta, estrogen receptor-alpha, and progesterone resistance in endometriosis. Seminars in Reproductive Medicine 28 36-43. (https:// doi.org/10.1055/s-0029-1242991)

Bulun SE, Monsavais D, Pavone ME, Dyson M, Xue Q, Attar E, Tokunaga H \& Su EJ 2012 Role of estrogen receptor-beta in endometriosis. Seminars in Reproductive Medicine 30 39-45. (https:// doi.org/10.1055/s-0031-1299596)

Bulun SE, Yilmaz BD, Sison C, Miyazaki K, Bernardi L, Liu S, Kohlmeier A, Yin P, Milad M \& Wei J 2019 Endometriosis. Endocrine Reviews 40 1048-1079. (https://doi.org/10.1210/er.2018-00242)

Burney RO, Talbi S, Hamilton AE, Vo KC, Nyegaard M, Nezhat CR, Lessey BA \& Giudice LC 2007 Gene expression analysis of endometrium reveals progesterone resistance and candidate susceptibility genes in women with endometriosis. Endocrinology 148 3814-3826. (https://doi.org/10.1210/en.2006-1692)

Burney RO, Hamilton AE, Aghajanova L, Vo KC, Nezhat CN, Lessey BA \& Giudice LC 2009 MicroRNA expression profiling of eutopic secretory endometrium in women with versus without endometriosis. Molecular Human Reproduction 15 625-631. (https://doi.org/10.1093/molehr/ gap068)

Burris TP, Solt LA, Wang Y, Crumbley C, Banerjee S, Griffett K, Lundasen T, Hughes T \& Kojetin DJ 2013 Nuclear receptors and their selective pharmacologic modulators. Pharmacological Reviews 65 710-778. (https://doi.org/10.1124/pr.112.006833)

Carlstrom K, Doberl A, Pousette A, Rannevik G \& Wilking N 1984 Inhibition of steroid sulfatase activity by danazol. Acta Obstetricia et Gynecologica Scandinavica: Supplement 123 107-111. (https://doi. org/10.3109/00016348409156994)

Carmeci C, Thompson DA, Ring HZ, Francke U \& Weigel RJ 1997 Identification of a gene (GPR30) with homology to the G-proteincoupled receptor superfamily associated with estrogen receptor expression in breast cancer. Genomics 45 607-617. (https://doi. org/10.1006/geno.1997.4972)

Carroll JS, Liu XS, Brodsky AS, Li W, Meyer CA, Szary AJ, Eeckhoute J, Shao W, Hestermann EV, Geistlinger TR, et al. 2005 Chromosomewide mapping of estrogen receptor binding reveals long-range regulation requiring the forkhead protein FoxA1. Cell 122 33-43. (https://doi.org/10.1016/j.cell.2005.05.008)

Carroll JS, Meyer CA, Song J, Li W, Geistlinger TR, Eeckhoute J, Brodsky AS, Keeton EK, Fertuck KC, Hall GF, et al. 2006 Genomewide analysis of estrogen receptor binding sites. Nature Genetics $\mathbf{3 8}$ 1289-1297. (https://doi.org/10.1038/ng1901)

Catalano RD, Wilson MR, Boddy SC \& Jabbour HN 2011 Comprehensive expression analysis of prostanoid enzymes and receptors in the human endometrium across the menstrual cycle. Molecular Human Reproduction 17 182-192. (https://doi.org/10.1093/molehr/gaq094)

Chapron C, Vannuccini S, Santulli P, Abrao MS, Carmona F, Fraser IS, Gordts S, Guo SW, Just PA, Noel JC, et al. 2020 Diagnosing adenomyosis: an integrated clinical and imaging approach. Human Reproduction Update 26 392-411. (https://doi.org/10.1093/humupd/ dmz049)

Chlebowski RT, Haque R, Hedlin H, Col N, Paskett E, Manson JE, Kubo JT, Johnson KC, Wactawski-Wende J, Pan K, et al. 2015 Benefit/risk for adjuvant breast cancer therapy with tamoxifen or aromatase inhibitor use by age, and race/ethnicity. Breast Cancer Research and Treatment 154 609-616. (https://doi.org/10.1007/ s10549-015-3647-1)

Colette S, Defrere S, Lousse JC, Van Langendonckt A, Gotteland JP, Loumaye E \& Donnez J 2011 Inhibition of steroid sulfatase decreases https://joe.bioscientifica.com https://doi.org/10.1530/JOE-20-0106 (c) 2020 Society for Endocrinology Published by Bioscientifica Ltd. Printed in Great Britain 
endometriosis in an in vivo murine model. Human Reproduction 26 1362-1370. (https://doi.org/10.1093/humrep/der079)

Collins F, Macpherson S, Brown P, Bombail V, Williams AR, Anderson RA, Jabbour HN \& Saunders PT 2009 Expression of oestrogen receptors, ERalpha, ERbeta, and ERbeta variants, in endometrial cancers and evidence that prostaglandin $\mathrm{F}$ may play a role in regulating expression of ERalpha. BMC Cancer 9 330. (https://doi.org/10.1186/1471-24079-330)

Collins F, Itani N, Esnal Zufiaurre A, Gibson DA, Fitzgerald C \& Saunders PT 2019 The ERbeta5 splice variant increases oestrogen responsiveness of ERalphapos Ishikawa cells. Endocrine-Related Cancer 27 55-66. (https://doi.org/10.1530/ERC-19-0291)

Cornel KMC, Bongers MY, Kruitwagen RPFM \& Romano A 2019 Local estrogen metabolism (intracrinology) in endometrial cancer: a systematic review. Molecular and Cellular Endocrinology 489 45-65. (https://doi.org/10.1016/j.mce.2018.10.004)

Cousins FL, Murray A, Esnal A, Gibson DA, Critchley HO \& Saunders PT 2014 Evidence from a mouse model that epithelial cell migration and mesenchymal-epithelial transition contribute to rapid restoration of uterine tissue integrity during menstruation. PLOS ONE 9 e86378 (https://doi.org/10.1371/journal.pone.0086378)

Cousins FL, Kirkwood PM, Murray AA, Collins F, Gibson DA \& Saunders PT 2016a Androgens regulate scarless repair of the endometrial 'wound' in a mouse model of menstruation. FASEB Journal 30 2802-2811. (https://doi.org/10.1096/fj.201600078R)

Cousins FL, Kirkwood PM, Saunders PT \& Gibson DA $2016 b$ Evidence for a dynamic role for mononuclear phagocytes during endometrial repair and remodelling. Scientific Reports 6 36748. (https://doi. org/10.1038/srep36748)

Critchley HO \& Saunders PT 2009 Hormone receptor dynamics in a receptive human endometrium. Reproductive Sciences 16 191-199. (https://doi.org/10.1177/1933719108331121)

Critchley HOD, Brenner RM, Henderson TA, Williams K, Nayak NR, Slayden OD, Millar MR \& Saunders PTK 2001 Estrogen receptor beta, but not estrogen receptor alpha, is present in the vascular endothelium of the human and nonhuman primate endometrium. Journal of Clinical Endocrinology and Metabolism 86 1370-1378. (https://doi.org/10.1210/jcem.86.3.7317)

Critchley HO, Henderson TA, Kelly RW, Scobie GS, Evans LR, Groome NP \& Saunders PT 2002 Wild-type estrogen receptor (ERbeta1) and the splice variant (ERbetacx/beta2) are both expressed within the human endometrium throughout the normal menstrual cycle. Journal of Clinical Endocrinology and Metabolism 87 5265-5273. (https://doi. org/10.1210/jc.2002-020502)

Dalton JT, Barnette KG, Bohl CE, Hancock ML, Rodriguez D, Dodson ST, Morton RA \& Steiner MS 2011 The selective androgen receptor modulator GTx-024 (enobosarm) improves lean body mass and physical function in healthy elderly men and postmenopausal women: results of a double-blind, placebo-controlled phase II trial. Journal of Cachexia, Sarcopenia and Muscle 2 153-161. (https://doi. org/10.1007/s13539-011-0034-6)

Das A, Mantena SR, Kannan A, Evans DB, Bagchi MK \& Bagchi IC 2009 De novo synthesis of estrogen in pregnant uterus is critical for stromal decidualization and angiogenesis. PNAS 106 12542-12547. (https://doi.org/10.1073/pnas.0901647106)

Day JM, Foster PA, Tutill HJ, Parsons MF, Newman SP, Chander SK, Allan GM, Lawrence HR, Vicker N, Potter BV, et al. 2008 17betaHydroxysteroid dehydrogenase type 1 , and not type 12 , is a target for endocrine therapy of hormone-dependent breast cancer. International Journal of Cancer 122 1931-1940. (https://doi. org/10.1002/ijc.23350)

Day JM, Purohit A, Tutill HJ, Foster PA, Woo LW, Potter BV \& Reed MJ 2009 The development of steroid sulfatase inhibitors for hormonedependent cancer therapy. Annals of the New York Academy of Sciences 1155 80-87. (https://doi.org/10.1111/j.1749-6632.2008.03677.x)
Dehm SM \& Tindall DJ 2011 Alternatively spliced androgen receptor variants. Endocrine-Related Cancer 18 R183-R196. (https://doi. org/10.1530/ERC-11-0141)

Delvoux B, D'Hooghe T, Kyama C, Koskimies P, Hermans RJ, Dunselman GA \& Romano A 2014 Inhibition of type 11 betahydroxysteroid dehydrogenase impairs the synthesis of 17betaestradiol in endometriosis lesions. Journal of Clinical Endocrinology and Metabolism 99 276-284. (https://doi.org/10.1210/jc.2013-2503)

Dennis MK, Field AS, Burai R, Ramesh C, Petrie WK, Bologa CG, Oprea TI, Yamaguchi Y, Hayashi S, Sklar LA, et al. 2011 Identification of a GPER/ GPR30 antagonist with improved estrogen receptor counterselectivity. Journal of Steroid Biochemistry and Molecular Biology 127 358-366. (https://doi.org/10.1016/j.jsbmb.2011.07.002)

Donnez J, Donnez O \& Dolmans MM 2018 Introduction: uterine adenomyosis, another enigmatic disease of our time. Fertility and Sterility 109 369-370. (https://doi.org/10.1016/j. fertnstert.2018.01.035)

Donnez J, Dolmans MM \& Fellah L 2019 What if deep endometriotic nodules and uterine adenomyosis were actually two forms of the same disease? Fertility and Sterility 111 454-456. (https://doi. org/10.1016/j.fertnstert.2018.12.018)

Dorostghoal M, Ghaffari HO, Marmazi F \& Keikhah N 2018 Overexpression of endometrial estrogen receptor-alpha in the window of implantation in women with unexplained infertility. International Journal of Fertility and Sterility 12 37-42. (https://doi.org/10.22074/ ijfs.2018.5118)

Dreisler E \& Kjer JJ 2019 Asherman's syndrome: current perspectives on diagnosis and management. International Journal of Women's Health $\mathbf{1 1}$ 191-198. (https://doi.org/10.2147/ijwh.s165474)

Dunselman GA, Vermeulen N, Becker C, Calhaz-Jorge C, D'Hooghe T, De Bie B, Heikinheimo O, Horne AW, Kiesel L, Nap A, et al. 2014 ESHRE guideline: management of women with endometriosis. Human Reproduction 29 400-412. (https://doi.org/10.1093/humrep/det457)

Fanning SW, Jeselsohn R, Dharmarajan V, Mayne CG, Karimi M, Buchwalter G, Houtman R, Toy W, Fowler CE, Han R, et al. 2018 The SERM/SERD bazedoxifene disrupts ESR1 helix 12 to overcome acquired hormone resistance in breast cancer cells. eLife $\mathbf{7}$ e37161. (https://doi.org/10.7554/eLife.37161)

Farquhar C, Prentice A, Singla AA \& Selak V 2007 Danazol for pelvic pain associated with endometriosis. Cochrane Database of Systematic Reviews 4 CD000068. (https://doi.org/10.1002/14651858.CD000068. pub2)

Fearnley EJ, Marquart L, Spurdle AB, Weinstein P, Webb PM \& Australian Ovarian Cancer Study Group and Australian National Endometrial Cancer Study Group 2010 Polycystic ovary syndrome increases the risk of endometrial cancer in women aged less than 50 years: an Australian case-control study. Cancer Causes and Control 21 2303-2308. (https://doi.org/10.1007/s10552-010-9658-7)

Flouriot G, Brand H, Denger S, Metivier R, Kos M, Reid G, Sonntag-Buck V \& Gannon F 2000 Identification of a new isoform of the human estrogen receptor-alpha (hER-alpha) that is encoded by distinct transcripts and that is able to repress hER-alpha activation function 1. EMBO Journal 19 4688-4700. (https://doi.org/10.1093/emboj/19.17.4688)

Frasor J, Barnett DH, Danes JM, Hess R, Parlow AF \& Katzenellenbogen BS 2003 Response-specific and ligand dose-dependent modulation of estrogen receptor (ER) alpha activity by ERbeta in the uterus. Endocrinology 144 3159-3166. (https://doi.org/10.1210/en.2002-0143)

Gao W \& Dalton JT 2007 Expanding the therapeutic use of androgens via selective androgen receptor modulators (SARMs). Drug Discovery Today 12 241-248. (https://doi.org/10.1016/j.drudis.2007.01.003)

Garry R, Hart R, Karthigasu KA \& Burke C 2009 A re-appraisal of the morphological changes within the endometrium during menstruation: a hysteroscopic, histological and scanning electron microscopic study. Human Reproduction 24 1393-1401. (https://doi. org/10.1093/humrep/dep036) https://joe.bioscientifica.com

https://doi.org/10.1530/JOE-20-0106 (c) 2020 Society for Endocrinology Published by Bioscientifica Ltd. Printed in Great Britain 
Gellersen B, Brosens IA \& Brosens JJ 2007 Decidualization of the human endometrium: mechanisms, functions, and clinical perspectives. Seminars in Reproductive Medicine 25 445-453. (https://doi. org/10.1055/s-2007-991042)

Gibson DA \& Saunders PT 2012 Estrogen dependent signaling in reproductive tissues - a role for estrogen receptors and estrogen related receptors. Molecular and Cellular Endocrinology 348 361-372. (https://doi.org/10.1016/j.mce.2011.09.026)

Gibson DA, McInnes KJ, Critchley HO \& Saunders PT 2013 Endometrial Intracrinology - generation of an estrogen-dominated microenvironment in the secretory phase of women. Journal of Clinical Endocrinology and Metabolism 98 E1802-E1806. (https://doi. org/10.1210/jc.2013-2140)

Gibson DA, Simitsidellis I, Collins F \& Saunders PT 2014 Evidence of androgen action in endometrial and ovarian cancers. EndocrineRelated Cancer 21 T203-T218. (https://doi.org/10.1530/ERC-13-0551)

Gibson DA, Greaves E, Critchley HO \& Saunders PT 2015 Estrogendependent regulation of human uterine natural killer cells promotes vascular remodelling via secretion of CCL2. Human Reproduction 30 1290-1301. (https://doi.org/10.1093/humrep/dev067)

Gibson DA, Simitsidellis I, Cousins FL, Critchley HO \& Saunders PT $2016 a$ Intracrine androgens enhance decidualization and modulate expression of human endometrial receptivity genes. Scientific Reports 6 19970. (https://doi.org/10.1038/srep19970)

Gibson DA, Simitsidellis I \& Saunders PT 2016b Regulation of androgen action during establishment of pregnancy. Journal of Molecular Endocrinology 57 R35-R47. (https://doi.org/10.1530/JME-16-0027)

Gibson DA, Foster PA, Simitsidellis I, Critchley HOD, Kelepouri O, Collins F \& Saunders PTK 2018a Sulfation PATHWAYS: a role for steroid sulphatase in intracrine regulation of endometrial decidualisation. Journal of Molecular Endocrinology 61 M57-M65. (https://doi.org/10.1530/JME-18-0037)

Gibson DA, Simitsidellis I, Collins F \& Saunders PTK $2018 b$ Endometrial intracrinology: oestrogens, androgens and endometrial disorders. International Journal of Molecular Sciences 19 3276. (https://doi. org/10.3390/ijms19103276)

Gibson DA, Simitsidellis I, Kelepouri O, Critchley HOD \& Saunders PTK $2018 c$ Dehydroepiandrosterone enhances decidualization in women of advanced reproductive age. Fertility and Sterility 109 728.e2-734.e2. (https://doi.org/10.1016/j.fertnstert.2017.12.024)

Gibson DA, Esnal-Zufiaurre A, Bajo-Santos C, Collins F, Critchley HOD \& Saunders PTK 2020 Profiling the expression and function of oestrogen receptor isoform ER46 in human endometrial tissues and uterine natural killer cells. Human Reproduction 35 641-651. (https://doi. org/10.1093/humrep/dez306)

Greaves E, Collins F, Critchley HO \& Saunders PT 2013 ERbeta-dependent effects on uterine endothelial cells are cell specific and mediated via Sp1. Human Reproduction 28 2490-2501. (https://doi.org/10.1093/ humrep/det235)

Greaves E, Collins F, Esnal-Zufiaurre A, Giakoumelou S, Horne AW \& Saunders PT 2014a Estrogen receptor (ER) agonists differentially regulate neuroangiogenesis in peritoneal endometriosis via the repellent factor SLIT3. Endocrinology 155 4015-4026. (https://doi. org/10.1210/en.2014-1086)

Greaves E, Cousins FL, Murray A, Esnal-Zufiaurre A, Fassbender A, Horne AW \& Saunders PT 2014b A novel mouse model of endometriosis mimics human phenotype and reveals insights into the inflammatory contribution of shed endometrium. American Journal of Pathology 184 1930-1939. (https://doi.org/10.1016/j. ajpath.2014.03.011)

Grimstad FW, Fowler KG, New EP, Ferrando CA, Pollard RR, Chapman G, Gomez-Lobo V \& Gray M 2019 Uterine pathology in transmasculine persons on testosterone: a retrospective multicenter case series. American Journal of Obstetrics and Gynecology 220 257.e1-257.e7. (https://doi.org/10.1016/j.ajog.2018.12.021)
Gronemeyer H, Gustafsson JA \& Laudet V 2004 Principles for modulation of the nuclear receptor superfamily. Nature Reviews: Drug Discovery 3 950-964. (https://doi.org/10.1038/nrd1551)

Guo SW \& Groothuis PG 2018 Is it time for a paradigm shift in drug research and development in endometriosis/adenomyosis? Human Reproduction Update 24 577-598. (https://doi.org/10.1093/humupd/ dmy020)

Hammes SR \& Levin ER 2007 Extranuclear steroid receptors: nature and actions. Endocrine Reviews 28 726-741. (https://doi.org/10.1210/ er.2007-0022)

Hapangama DK, Kamal AM \& Bulmer JN 2015 Estrogen receptor beta: the guardian of the endometrium. Human Reproduction Update $\mathbf{2 1}$ 174-193. (https://doi.org/10.1093/humupd/dmu053)

Harris HA 2006 The unexpected science of estrogen receptor-beta selective agonists: a new class of anti-inflammatory agents? Nuclear Receptor Signaling 4 e012. (https://doi.org/10.1621/nrs.04012)

He B, Lanz RB, Fiskus W, Geng C, Yi P, Hartig SM, Rajapakshe K, Shou J, Wei L, Shah SS, et al. 2014 GATA2 facilitates steroid receptor coactivator recruitment to the androgen receptor complex. PNAS 111 18261-18266. (https://doi.org/10.1073/ pnas.1421415111)

Herndon CN, Aghajanova L, Balayan S, Erikson D, Barragan F, Goldfien G, Vo KC, Hawkins S \& Giudice LC 2016 Global transcriptome abnormalities of the eutopic endometrium from women with adenomyosis. Reproductive Sciences 23 1289-1303. (https://doi.org/10.1177/1933719116650758)

Hewitt SC \& Korach KS 2003 Oestrogen receptor knockout mice: roles for oestrogen receptors alpha and beta in reproductive tissues. Reproduction 125 143-149. (https://doi.org/10.1530/rep.0.1250143)

Hickey TE, Irvine CM, Dvinge H, Tarulli GA, Hanson AR, Ryan NK, Pickering MA, Birrell SN, Hu DG, Mackenzie PI, et al. 2015 Expression of androgen receptor splice variants in clinical breast cancers. Oncotarget 6 44728-44744. (https://doi.org/10.18632/ oncotarget.6296)

Hong DG, Park JY, Chong GO, Lee YH, Lee HJ, Shinn JU, Lee YS \& Seong WJ 2019 Transmembrane G protein-coupled receptor 30 gene polymorphisms and uterine adenomyosis in Korean women. Gynecological Endocrinology 35 498-501. (https://doi.org/10.1080/095 13590.2018.1540572)

Horard B \& Vanacker JM 2003 Estrogen receptor-related receptors: orphan receptors desperately seeking a ligand. Journal of Molecular Endocrinology 31 349-357. (https://doi.org/10.1677/jme.0.0310349)

Horie K, Takakura K, Imai K, Liao S \& Mori T 1992 Immunohistochemical localization of androgen receptor in the human endometrium, decidua, placenta and pathological conditions of the endometrium. Human Reproduction 7 1461-1466. (https://doi.org/10.1093/ oxfordjournals.humrep.a137595)

Horne AW \& Saunders PTK 2019 SnapShot: endometriosis. Cell 1791677. e1-1677.e1. (https://doi.org/10.1016/j.cell.2019.11.033)

Horne AW, Saunders PTK, Abokhrais IM, Hogg L \& Endometriosis Priority Setting Partnership Steering Group 2017 Top ten endometriosis research priorities in the UK and Ireland. Lancet 389 2191-2192. (https://doi.org/10.1016/s0140-6736(17)31344-2)

Huhtinen K, Stahle M, Perheentupa A \& Poutanen M 2012 Estrogen biosynthesis and signaling in endometriosis. Molecular and Cellular Endocrinology 358 146-154. (https://doi.org/10.1016/j. mce.2011.08.022)

Huhtinen K, Saloniemi-Heinonen T, Keski-Rahkonen P, Desai R, Laajala D, Stahle M, Hakkinen MR, Awosanya M, Suvitie P, Kujari H, et al. 2014 Intra-tissue steroid profiling indicates differential progesterone and testosterone metabolism in the endometrium and endometriosis lesions. Journal of Clinical Endocrinology and Metabolism 99 E2188-E2197. (https://doi.org/10.1210/jc.2014-1913)

Ito K, Miki Y, Suzuki T, McNamara KM \& Sasano H 2016 In situ androgen and estrogen biosynthesis in endometrial cancer: focus on androgen https://joe.bioscientifica.com

https://doi.org/10.1530/JOE-20-0106
(C) 2020 Society for Endocrinology Published by Bioscientifica Ltd. Printed in Great Britain 
actions and intratumoral production. Endocrine-Related Cancer $\mathbf{2 3}$ R323-R335. (https://doi.org/10.1530/ERC-15-0470)

Jacenik D, Cygankiewicz AI \& Krajewska WM 2016 The G proteincoupled estrogen receptor as a modulator of neoplastic transformation. Molecular and Cellular Endocrinology 429 10-18. (https://doi.org/10.1016/j.mce.2016.04.011)

Jordan VC 2003 Tamoxifen: a most unlikely pioneering medicine. Nature Reviews Drug Discovery 2 205-213. (https://doi.org/10.1016/j. drudis.2007.01.003)

Kajihara T, Tochigi H, Prechapanich J, Uchino S, Itakura A, Brosens JJ \& Ishihara O 2012 Androgen signaling in decidualizing human endometrial stromal cells enhances resistance to oxidative stress. Fertility and Sterility 97 185-191. (https://doi.org/10.1016/j. fertnstert.2011.10.017)

Kamal AM, Bulmer JN, DeCruze SB, Stringfellow HF, Martin-Hirsch P \& Hapangama DK 2016 Androgen receptors are acquired by healthy postmenopausal endometrial epithelium and their subsequent loss in endometrial cancer is associated with poor survival. British Journal of Cancer 114 688-696. (https://doi.org/10.1038/bjc.2016.16)

Kauppila A, Isotalo H, Kivinen S, Stenback F \& Vihko R 1985 Short-term effects of danazol and medroxyprogesterone acetate on cytosol and nuclear estrogen and progestin receptors, 17 beta-hydroxysteroid dehydrogenase activity, histopathology, and ultrastructure of human endometrial adenocarcinoma. International Journal of Cancer $\mathbf{3 5}$ 157-163. (https://doi.org/10.1002/ijc.2910350203)

Kearbey JD, Gao W, Narayanan R, Fisher SJ, Wu D, Miller DD \& Dalton JT 2007 Selective androgen receptor modulator (SARM) treatment prevents bone loss and reduces body fat in ovariectomized rats. Pharmaceutical Research 24 328-335. (https://doi.org/10.1007/s11095006-9152-9)

Khine YM, Taniguchi F, Nagira K, Nakamura K, Ohbayashi T, Osaki M \& Harada T 2018 New insights into the efficacy of SR-16234, a selective estrogen receptor modulator, on the growth of murine endometriosislike lesions. American Journal of Reproductive Immunology $\mathbf{8 0}$ e13023. (https://doi.org/10.1111/aji.13023)

Kieser KJ, Kim DW, Carlson KE, Katzenellenbogen BS \& Katzenellenbogen JA 2010 Characterization of the pharmacophore properties of novel selective estrogen receptor downregulators (SERDs). Journal of Medicinal Chemistry 53 3320-3329. (https://doi. org $/ 10.1021 /$ jm100047k)

Kitawaki J, Koshiba H, Ishihara H, Kusuki I, Tsukamoto K \& Honjo H 2000 Progesterone induction of 17beta-hydroxysteroid dehydrogenase type 2 during the secretory phase occurs in the endometrium of estrogen-dependent benign diseases but not in normal endometrium. Journal of Clinical Endocrinology and Metabolism 85 3292-3296. (https://doi.org/10.1210/jcem.85.9.6829)

Kolkova Z, Noskova V, Ehinger A, Hansson S \& Casslen B 2010 G Protein-coupled estrogen receptor 1 (GPER, GPR 30) in normal human endometrium and early pregnancy decidua. Molecular Human Reproduction 16 743-751. (https://doi.org/10.1093/molehr/gaq043)

Konings G, Brentjens L, Delvoux B, Linnanen T, Cornel K, Koskimies P, Bongers M, Kruitwagen R, Xanthoulea S \& Romano A 2018 Intracrine regulation of estrogen and other sex steroid levels in endometrium and non-gynecological tissues; pathology, physiology, and drug discovery. Frontiers in Pharmacology 9 940. (https://doi.org/10.3389/ fphar.2018.00940)

Kulak Jr J, Fischer C, Komm B \& Taylor HS 2011 Treatment with Bazedoxifene, a selective estrogen receptor modulator, causes regression of endometriosis in a mouse model. Endocrinology 152 3226-3232. (https://doi.org/10.1210/en.2010-1010)

Labrie F 2019 Intracrinology and menopause: the science describing the cell-specific intracellular formation of estrogens and androgens from DHEA and their strictly local action and inactivation in peripheral tissues. Menopause 26 220-224. (https://doi.org/10.1097/ GME.0000000000001177)
Labrie F, Luu-The V, Belanger A, Lin SX, Simard J, Pelletier G \& Labrie C 2005 Is dehydroepiandrosterone a hormone? Journal of Endocrinology 187 169-196. (https://doi.org/10.1677/joe.1.06264)

Langdon SP, Gourley C, Gabra H \& Stanley B 2017 Endocrine therapy in epithelial ovarian cancer. Expert Review of Anticancer Therapy 17 109-117. (https://doi.org/10.1080/14737140.2017.1272414)

Lannigan DA 2003 Estrogen receptor phosphorylation. Steroids 68 1-9. (https://doi.org/10.1016/s0039-128x(02)00110-1)

Lash GE, Bulmer JN, Li TC, Innes BA, Mariee N, Patel G, Sanderson J, Quenby S \& Laird SM 2016 Standardisation of uterine natural killer (uNK) cell measurements in the endometrium of women with recurrent reproductive failure. Journal of Reproductive Immunology 116 50-59. (https://doi.org/10.1016/j.jri.2016.04.290)

Lavery DN \& McEwan IJ 2008 Functional characterization of the native NH2-terminal transactivation domain of the human androgen receptor: binding kinetics for interactions with TFIIF and SRC-1a. Biochemistry 47 3352-3359. (https://doi.org/10.1021/bi702220p)

Lecce G, Meduri G, Ancelin M, Bergeron C \& Perrot-Applanat M 2001 Presence of estrogen receptor beta in the human endometrium through the cycle: expression in glandular, stromal, and vascular cells. Journal of Clinical Endocrinology and Metabolism 86 1379-1386. (https://doi.org/10.1210/jcem.86.3.7322)

Lessey BA \& Kim JJ 2017 Endometrial receptivity in the eutopic endometrium of women with endometriosis: it is affected, and let me show you why. Fertility and Sterility 108 19-27. (https://doi. org/10.1016/j.fertnstert.2017.05.031)

Lessey BA, Killam AP, Metzger DA, Haneyt AF, Greene GL \& McKarty KS 1988 Immunohistochemical analysis of human uterine oestrogen and progesterone receptors throughout the menstrual cycle. Journal of Clinical Endocrinology and Metabolism 67 334-340. (https://doi. org/10.1210/jcem-67-2-334)

Lessey BA, Palomino WA, Apparao KB, Young SL \& Lininger RA 2006 Estrogen receptor-alpha (ER-alpha) and defects in uterine receptivity in women. Reproductive Biology and Endocrinology 4 (Supplement 1) S9. (https://doi.org/10.1186/1477-7827-4-S1-S9)

Li JJ, Duan H, Wang S, Sun FQ, Gan L, Tang YQ, Xu Q \& Li TC 2017 Expression pattern of G-protein-coupled estrogen receptor in myometrium of uteri with and without adenomyosis. BioMed Research International 2017 5974693. (https://doi. org $/ 10.1155 / 2017 / 5974693)$

Lindemann K, Malander S, Christensen RD, Mirza MR, Kristensen GB, Aavall-Lundqvist E, Vergote I, Rosenberg P, Boman K \& Nordstrom B 2014 Examestane in advanced or recurrent endometrial carcinoma: a prospective phase II study by the Nordic Society of Gynecologic Oncology (NSGO). BMC Cancer 14 68. (https://doi.org/10.1186/14712407-14-68)

Lucas ES, Vrljicak P, Muter J, Diniz-da-Costa MM, Brighton PJ, Kong C-S, Lipecki J, Fishwick KJ, Odendaal J, Ewington LJ, et al. 2020 Recurrent pregnancy loss is associated with a pro-senescent decidual response during the peri-implantation window. Communications Biology 337. (https://doi.org/10.1038/s42003-020-0763-1)

Maentausta O, Sormunen R, Isomaa V, Lehto VP, Jouppila P \& Vihko R 1991 Immunohistochemical localization of 17 beta-hydroxysteroid dehydrogenase in the human endometrium during the menstrual cycle. Laboratory Investigation 65 582-587.

Mao X, Dong B, Gao M, Ruan G, Huang M, Braicu EI, Sehouli J \& Sun P 2019 Dual targeting of estrogen receptor alpha and estrogen-related receptor alpha: a novel endocrine therapy for endometrial cancer. OncoTargets and Therapy 12 6757-6767. (https://doi.org/10.2147/OTT. S216146)

Marshall E, Lowrey J, Macpherson S, Maybin JA, Collins F, Critchley HO \& Saunders PT 2011 In silico analysis identifies a novel role for androgens in the regulation of human endometrial apoptosis. Journal of Clinical Endocrinology and Metabolism 96 E1746-E1755. (https://doi. org/10.1210/jc.2011-0272) https://joe.bioscientifica.com

https://doi.org/10.1530/JOE-20-0106 (c) 2020 Society for Endocrinology Published by Bioscientifica Ltd. Printed in Great Britain 
Maybin JA \& Critchley HO 2016 Medical management of heavy menstrual bleeding. Women's Health 12 27-34. (https://doi. org $/ 10.2217 /$ whe.15.100)

McEwan IJ 2013 Androgen receptor modulators: a marriage of chemistry and biology. Future Medicinal Chemistry 5 1109-1120. (https://doi org/10.4155/fmc.13.69)

McKenna NJ, Lanz RB \& O'Malley BW 1999 Nuclear receptor co-regulators: cellular and molecular biology. Endocrine Reviews 20 321-344. (https://doi.org/10.1210/edrv.20.3.0366)

McKinnon B, Mueller M \& Montgomery G 2018 Progesterone resistance in endometriosis: an acquired property? Trends in Endocrinology and Metabolism 29 535-548. (https://doi.org/10.1016/j.tem.2018.05.006)

Mehasseb MK, Panchal R, Taylor AH, Brown L, Bell SC \& Habiba M 2011 Estrogen and progesterone receptor isoform distribution through the menstrual cycle in uteri with and without adenomyosis. Fertility and Sterility 95 2228.e1-2235.e1, 2235.e2221. (https://doi.org/10.1016/j. fertnstert.2011.02.051)

Meyer MR, Prossnitz ER \& Barton M 2011 The G protein-coupled estrogen receptor GPER/GPR30 as a regulator of cardiovascular function. Vascular Pharmacology 55 17-25. (https://doi.org/10.1016/j. vph.2011.06.003)

Mileshkin L, Edmondson R, O'Connell RL, Sjoquist KM, Andrews J, Jyothirmayi R, Beale P, Bonaventura T, Goh J, Hall M, et al. 2019 Phase 2 study of anastrozole in recurrent estrogen (ER)/progesterone (PR) positive endometrial cancer: the Paragon trial - ANZGOG 0903. Gynecologic Oncology 154 29-37. (https://doi.org/10.1016/j. ygyno.2019.05.007)

Miller WR, Dixon JM, Cameron DA \& Anderson TJ 2001 Biological and clinical effects of aromatase inhibitors in neoadjuvant therapy. Journal of Steroid Biochemistry and Molecular Biology 79 103-107. (https://doi. org/10.1016/s0960-0760(01)00149-2)

Miravet-Valenciano J, Ruiz-Alonso M, Gomez E \& Garcia-Velasco JA 2017 Endometrial receptivity in eutopic endometrium in patients with endometriosis: it is not affected, and let me show you why. Fertility and Sterility 108 28-31. (https://doi.org/10.1016/j. fertnstert.2017.06.002)

Mori T, Ito F, Matsushima H, Takaoka O, Tanaka Y, Koshiba A, Kusuki I \& Kitawaki J 2015 G Protein-coupled estrogen receptor 1 agonist G-1 induces cell cycle arrest in the mitotic phase, leading to apoptosis in endometriosis. Fertility and Sterility 103 1228.e1-1235.e1. (https://doi. org/10.1016/j.fertnstert.2015.01.026)

Muchmore DB 2000 Raloxifene: a selective estrogen receptor modulator (SERM) with multiple target system effects. Oncologist 5 388-392. (https://doi.org/10.1634/theoncologist.5-5-388)

Nadal M, Prekovic S, Gallastegui N, Helsen C, Abella M, Zielinska K, Gay M, Vilaseca M, Taules M, Houtsmuller AB, et al. 2017 Structure of the homodimeric androgen receptor ligand-binding domain. Nature Communications 8 14388. (https://doi.org/10.1038/ncomms14388)

Naftalin J, Hoo W, Pateman K, Mavrelos D, Holland T \& Jurkovic D 2012 How common is adenomyosis? A prospective study of prevalence using transvaginal ultrasound in a gynaecology clinic. Human Reproduction 27 3432-3439. (https://doi.org/10.1093/humrep/des332)

Narayanan R, Coss CC \& Dalton JT 2018 Development of selective androgen receptor modulators (SARMs). Molecular and Cellular Endocrinology 465 134-142. (https://doi.org/10.1016/j. mce.2017.06.013)

Narvekar N, Cameron S, Critchley HO, Lin S, Cheng L \& Baird DT 2004 Low-dose mifepristone inhibits endometrial proliferation and up-regulates androgen receptor. Journal of Clinical Endocrinology and Metabolism 89 2491-2497. (https://doi.org/10.1210/jc.2003-031945)

Neil D, Clark RV, Magee M, Billiard J, Chan A, Xue Z \& Russell A 2018 GSK2881078, a SARM, produces dose-dependent increases in lean mass in healthy older men and women. Journal of Clinical Endocrinology and Metabolism 103 3215-3224. (https://doi. org/10.1210/jc.2017-02644)
Noyes RW, Hertig AT \& Rock J 1975 Dating the endometrial biopsy. American Journal of Obstetrics and Gynecology 122 262-263. (https:// doi.org/10.1016/s0002-9378(16)33500-1)

Omlin A, Jones JR, van der Noll R, Satoh T, Niwakawa M, Smith SA, Graham J, Ong M, Finkelman RD, Schellens JH, et al. 2015 AZD3514, an oral selective androgen receptor down-regulator in patients with castration-resistant prostate cancer - results of two parallel first-inhuman phase I studies. Investigational New Drugs 33 679-690. (https:// doi.org/10.1007/s10637-015-0235-5)

Palmieri C, Stein RC, Liu X, Hudson E, Nicholas H, Sasano H, Guestini F, Holcombe C, Barrett S, Kenny L, et al. 2017 IRIS study: a phase II study of the steroid sulfatase inhibitor Irosustat when added to an aromatase inhibitor in ER-positive breast cancer patients. Breast Cancer Research and Treatment 165 343-353. (https://doi.org/10.1007/ s10549-017-4328-z)

Pannier D, Cordoba A, Ryckewaert T, Robin YM \& Penel N 2019 Hormonal therapies in uterine sarcomas, aggressive angiomyxoma, and desmoid-type fibromatosis. Critical Reviews in Oncology/Hematology 143 62-66. (https://doi.org/10.1016/j. critrevonc.2019.08.007)

Pati T, Chanania K, Marandi S \& Hansa J 2017 Ormeloxifene - Looking beyond contraception. Journal of Mid-Life Health 8 17-20. (https://doi. org/10.4103/jmh.JMH_71_16)

Pautier P, Vergote I, Joly F, Melichar B, Kutarska E, Hall G, Lisyanskaya A, Reed N, Oaknin A, Ostapenko V, et al. 2017 A phase 2, randomized, open-label study of irosustat versus megestrol acetate in advanced endometrial cancer. International Journal of Gynecological Cancer $\mathbf{2 7}$ 258-266. (https://doi.org/10.1097/IGC.0000000000000862)

Pavone ME \& Bulun SE 2012 Aromatase inhibitors for the treatment of endometriosis. Fertility and Sterility 98 1370-1379. (https://doi. org/10.1016/j.fertnstert.2012.08.053)

Pawar S, Laws MJ, Bagchi IC \& Bagchi MK 2015 Uterine epithelial estrogen receptor-alpha controls decidualization via a paracrine mechanism. Molecular Endocrinology 29 1362-1374. (https://doi. org/10.1210/me.2015-1142)

Pepermans RA \& Prossnitz ER 2019 ERalpha-targeted endocrine therapy, resistance and the role of GPER. Steroids 152 108493. (https://doi. org/10.1016/j.steroids.2019.108493)

Petrie WK, Dennis MK, Hu C, Dai D, Arterburn JB, Smith HO, Hathaway HJ \& Prossnitz ER 2013 G Protein-coupled estrogen receptor-selective ligands modulate endometrial tumor growth. Obstetrics and Gynecology International 2013 472720. (https://doi. org/10.1155/2013/472720)

Petz LN, Ziegler YS, Schultz JR, Kim H, Kemper JK \& Nardulli AM 2004 Differential regulation of the human progesterone receptor gene through an estrogen response element half site and Sp1 sites. Journal of Steroid Biochemistry and Molecular Biology 88 113-122. (https://doi. org/10.1016/j.jsbmb.2003.11.008)

Pickar JH, Boucher M \& Morgenstern D 2018 Tissue selective estrogen complex (TSEC): a review. Menopause 25 1033-1045. (https://doi. org/10.1097/GME.0000000000001095)

Plante BJ, Lessey BA, Taylor RN, Wang W, Bagchi MK, Yuan L, Scotchie J, Fritz MA \& Young SL 2012 G Protein-coupled estrogen receptor (GPER) expression in normal and abnormal endometrium. Reproductive Sciences 19 684-693. (https://doi. org/10.1177/1933719111431000)

Pohl O, Bestel E \& Gotteland JP 2014 Synergistic effects of E2MATE and norethindrone acetate on steroid sulfatase inhibition: a randomized phase I proof-of-principle clinical study in women of reproductive age. Reproductive Sciences 21 1256-1265. (https://doi. org/10.1177/1933719114522526)

Ponnusamy S, He Y, Hwang DJ, Thiyagarajan T, Houtman R, Bocharova V, Sumpter BG, Fernandez E, Johnson D, Du Z, et al. 2019 Orally bioavailable androgen receptor degrader, potential next-generation therapeutic for enzalutamide-resistant prostate cancer. Clinical Cancer https://joe.bioscientifica.com

https://doi.org/10.1530/JOE-20-0106
(C) 2020 Society for Endocrinology Published by Bioscientifica Ltd. Printed in Great Britain 
Research 25 6764-6780. (https://doi.org/10.1158/1078-0432.CCR-191458)

Pontis A, D'Alterio MN, Pirarba S, de Angelis C, Tinelli R \& Angioni S 2016 Adenomyosis: a systematic review of medical treatment. Gynecological Endocrinology 32 696-700. (https://doi.org/10.1080/095 13590.2016.1197200)

Potter BVL 2018 SULFATION PATHWAYS: Steroid sulphatase inhibition via aryl sulphamates: clinical progress, mechanism and future prospects. Journal of Molecular Endocrinology 61 T233-T252. (https:// doi.org/10.1530/JME-18-0045)

Prossnitz ER \& Hathaway HJ 2015 What have we learned about GPER function in physiology and disease from knockout mice? Journal of Steroid Biochemistry and Molecular Biology 153 114-126. (https://doi. org/10.1016/j.jsbmb.2015.06.014)

Purohit A \& Foster PA 2012 Steroid sulfatase inhibitors for estrogen- and androgen-dependent cancers. Journal of Endocrinology 212 99-110. (https://doi.org/10.1530/JOE-11-0266)

Quenby S, Nik H, Innes B, Lash G, Turner M, Drury J \& Bulmer J 2009 Uterine natural killer cells and angiogenesis in recurrent reproductive failure. Human Reproduction 24 45-54. (https://doi.org/10.1093/ humrep/den348)

Rizner TL 2009 Estrogen metabolism and action in endometriosis. Molecular and Cellular Endocrinology 307 8-18. (https://doi. org/10.1016/j.mce.2009.03.022)

Rizner TL 2016 The important roles of steroid sulfatase and sulfotransferases in gynecological diseases. Frontiers in Pharmacology $\mathbf{7}$ 30. (https://doi.org/10.3389/fphar.2016.00030)

Rizner TL \& Penning TM 2020 Aldo-keto reductase 1C3-Assessment as a new target for the treatment of endometriosis. Pharmacological Research 152 104446. (https://doi.org/10.1016/j.phrs.2019.104446)

Ryan NAJ, Glaire MA, Blake D, Cabrera-Dandy M, Evans DG \& Crosbie EJ 2019 The proportion of endometrial cancers associated with Lynch syndrome: a systematic review of the literature and meta-analysis Genetics in Medicine 21 2167-2180. (https://doi.org/10.1038/s41436019-0536-8)

Sanderson PA, Critchley HO, Williams AR, Arends MJ \& Saunders PT 2017 New concepts for an old problem: the diagnosis of endometrial hyperplasia. Human Reproduction Update 23 232-254. (https://doi. org/10.1093/humupd/dmw042)

Santen RJ, Brodie H, Simpson ER, Siiteri PK \& Brodie A 2009 History of aromatase: saga of an important biological mediator and therapeutic target. Endocrine Reviews 30 343-375. (https://doi.org/10.1210/ er.2008-0016)

Sasano H, Kaga K, Sato S, Yajima A, Nagura H \& Harada N 1996 Aromatase cytochrome $\mathrm{P} 450$ gene expression in endometrial carcinoma. British Journal of Cancer 74 1541-1544. (https://doi. org/10.1038/bjc.1996.586)

Saunders PT, Millar MR, Macpherson S, Irvine DS, Groome NP, Evans LR, Sharpe RM \& Scobie GA 2002 ERbeta1 and the ERbeta2 splice variant (ERbetacx/beta2) are expressed in distinct cell populations in the adult human testis. Journal of Clinical Endocrinology and Metabolism $\mathbf{8 7}$ 2706-2715. (https://doi.org/10.1210/jcem.87.6.8619)

Schulte MM, Tsai JH \& Moley KH 2015 Obesity and PCOS: the effect of metabolic derangements on endometrial receptivity at the time of implantation. Reproductive Sciences 22 6-14. (https://doi. org/10.1177/1933719114561552)

Schultze-Mosgau MH, Waellnitz K, Nave R, Klein S, Kraetzschmar J, Rautenberg T, Schmitz H \& Rohde B 2016 Pharmacokinetics, pharmacodynamics, safety and tolerability of an intravaginal ring releasing anastrozole and levonorgestrel in healthy premenopausal women: a Phase 1 randomized controlled trial. Human Reproduction 31 1713-1722. (https://doi.org/10.1093/humrep/dew145)

Shaaban AM, Green AR, Karthik S, Alizadeh Y, Hughes TA, Harkins L, Ellis IO, Robertson JF, Paish EC, Saunders PT, et al. 2008 Nuclear and cytoplasmic expression of ERbeta1, ERbeta2, and ERbeta5 identifies distinct prognostic outcome for breast cancer patients. Clinical Cancer
Research 14 5228-5235. (https://doi.org/10.1158/1078-0432.CCR-074528)

Shiau AK, Barstad D, Loria PM, Cheng L, Kushner PJ, Agard DA \& Greene GL 1998 The structural basis of estrogen receptor/coactivator recognition and the antagonism of this interaction by tamoxifen. Cell 95 927-937. (https://doi.org/10.1016/s0092-8674(00)81717-1)

Sierens JE, Scobie GA, Wilson J \& Saunders PT 2004 Cloning of oestrogen receptor beta from old and new world primates: identification of splice variants and functional analysis. Journal of Molecular Endocrinology 32 703-718. (https://doi.org/10.1677/jme.0.0320703)

Simitsidellis I, Esnal-Zuffiaure A, Kelepouri O, O'Flaherty E, Gibson DA \& Saunders PTK 2019 Selective androgen receptor modulators (SARMs) have specific impacts on the mouse uterus. Journal of Endocrinology 242 227-239. (https://doi.org/10.1530/JOE-19-0153)

Smith HO, Leslie KK, Singh M, Qualls CR, Revankar CM, Joste NE \& Prossnitz ER 2007 GPR30: a novel indicator of poor survival for endometrial carcinoma. American Journal of Obstetrics and Gynecology 196 386.e381-386.e389; discussion 386.e389-386.e311. (https://doi. org/10.1016/j.ajog.2007.01.004)

Sun FQ, Duan H, Wang S \& Li JJ 2015 17 $\beta$-Estradiol induces overproliferation in adenomyotic human uterine smooth muscle cells of the junctional zone through hyperactivation of the estrogen receptor-enhanced RhoA/ROCK signaling pathway. Reproductive Sciences 22 1436-1444. (https://doi.org/10.1177/1933719115584447)

Tanaka S, Miki Y, Hashimoto C, Takagi K, Doe Z, Li B, Yaegashi N, Suzuki T \& Ito K 2015 The role of 5alpha-reductase type 1 associated with intratumoral dihydrotestosterone concentrations in human endometrial carcinoma. Molecular and Cellular Endocrinology $\mathbf{4 0 1}$ 56-64. (https://doi.org/10.1016/j.mce.2014.11.022)

Utsunomiya H, Suzuki T, Kaneko C, Takeyama J, Nakamura J, Kimura K, Yoshihama M, Harada N, Ito K, Konno R, et al. 2001 The analyses of 17 beta-hydroxysteroid dehydrogenase isozymes in human endometrial hyperplasia and carcinoma. Journal of Clinical Endocrinology and Metabolism 86 3436-3443. (https://doi.org/10.1210/ jcem.86.7.7661)

Utsunomiya H, Ito K, Suzuki T, Kitamura T, Kaneko C, Nakata T, Niikura H, Okamura K, Yaegashi N \& Sasano H 2004 Steroid sulfatase and estrogen sulfotransferase in human endometrial carcinoma. Clinical Cancer Research 10 5850-5856. (https://doi. org/10.1158/1078-0432.CCR-04-0040)

van Weelden WJ, Massuger LFAG, ENITEC, Pijnenborg JMA \& Romano A 2019 Anti-estrogen treatment in endometrial cancer: a systematic review. Frontiers in Oncology 9 359. (https://doi.org/10.3389/ fonc.2019.00359)

Vannuccini S, Luisi S, Tosti C, Sorbi F \& Petraglia F 2018 Role of medical therapy in the management of uterine adenomyosis. Fertility and Sterility 109 398-405. (https://doi.org/10.1016/j.fertnstert.2018.01.013)

Wangtrakuldee P, Adeniji AO, Zang T, Duan L, Khatri B, Twenter BM, Estrada MA, Higgins TF, Winkler JD \& Penning TM 2019 A 3-(4-nitronaphthen-1-yl) amino-benzoate analog as a bifunctional AKR1C3 inhibitor and AR antagonist: head to head comparison with other advanced AKR1C3 targeted therapeutics. Journal of Steroid Biochemistry and Molecular Biology 192 105283. (https://doi. org/10.1016/j.jsbmb.2019.01.001)

Whitaker L \& Critchley HOD 2016 Abnormal uterine bleeding. Best Practice \& Research Clinical Obstetrics \& Gynaecology 34 54-65. (https:// doi.org/10.1016/j.bpobgyn.2015.11.012)

Whitaker LH, Murray AA, Matthews R, Shaw G, Williams AR, Saunders PT \& Critchley HO 2017 Selective progesterone receptor modulator (SPRM) ulipristal acetate (UPA) and its effects on the human endometrium. Human Reproduction 32 531-543. (https://doi. org/10.1093/humrep/dew359)

Wilkenfeld SR, Lin C \& Frigo DE 2018 Communication between genomic and non-genomic signaling events coordinate steroid hormone actions. Steroids 133 2-7. (https://doi.org/10.1016/j. steroids.2017.11.005) https://joe.bioscientifica.com

https://doi.org/10.1530/JOE-20-0106 (c) 2020 Society for Endocrinology Published by Bioscientifica Ltd. Printed in Great Britain 
Winuthayanon W, Hewitt SC \& Korach KS 2014 Uterine epithelial cell estrogen receptor alpha-dependent and -independent genomic profiles that underlie estrogen responses in mice. Biology of Reproduction 91 110. (https://doi.org/10.1095/biolreprod.114.120170)

Winuthayanon W, Lierz SL, Delarosa KC, Sampels SR, Donoghue LJ, Hewitt SC \& Korach KS 2017 Juxtacrine activity of estrogen receptor alpha in uterine stromal cells is necessary for estrogen-induced epithelial cell proliferation. Scientific Reports 7 8377. (https://doi. org/10.1038/s41598-017-07728-1)

Xiang Y, Sun Y, Yang B, Yang Y, Zhang Y, Yu T, Huang H, Zhang J \& Xu H 2019 Transcriptome sequencing of adenomyosis eutopic endometrium: a new insight into its pathophysiology. Journal of Cellular and Molecular Medicine 23 8381-8391. (https://doi. org/10.1111/jcmm.14718)

Ye R, Pi M, Nooh MM, Bahout SW \& Quarles LD 2019 Human GPRC6A mediates testosterone-induced mitogen-activated protein kinases and mTORC1 signaling in prostate cancer cells. Molecular Pharmacology 95 563-572. (https://doi.org/10.1124/mol.118.115014)
Young SL 2013 Oestrogen and progesterone action on endometrium: a translational approach to understanding endometrial receptivity. Reproductive Biomedicine Online 27 497-505. (https://doi.org/10.1016/j. rbmo.2013.06.010)

Yovich JL, Rowlands PK, Lingham S, Sillender M \& Srinivasan S 2020 Pathogenesis of endometriosis: look no further than John Sampson. Reproductive Biomedicine Online 40 7-11. (https://doi.org/10.1016/j. rbmo.2019.10.007)

Zhang L, Xiong W, Li N, Liu H, He H, Du Y, Zhang Z \& Liu Y 2017 Estrogen stabilizes hypoxia-inducible factor 1alpha through $\mathrm{G}$ protein-coupled estrogen receptor 1 in eutopic endometrium of endometriosis. Fertility and Sterility 107 439-447. (https://doi. org/10.1016/j.fertnstert.2016.11.008)

Zhu BT, Han GZ, Shim JY, Wen Y \& Jiang XR 2006 Quantitative structureactivity relationship of various endogenous estrogen metabolites for human estrogen receptor alpha and beta subtypes: insights into the structural determinants favoring a differential subtype binding. Endocrinology 147 4132-4150. (https://doi.org/10.1210/en.2006-0113)

Received in final form 15 May 2020

Accepted 16 June 2020

Accepted Manuscript published online 16 June 2020 (c) 2020 Society for Endocrinology Published by Bioscientifica Ltd.
Printed in Great Britain 